\title{
A Review on the Extraction and Processing of Natural Source-Derived Proteins through Eco-Innovative Approaches
}

\author{
Giselle Franca-Oliveira, Tiziana Fornari and Blanca Hernández-Ledesma *D \\ Institute of Food Science Research (CIAL, CSIC-UAM, CEI UAM+CSIC), Nicolás Cabrera, 28049 Madrid, Spain; \\ gisellefrancaoliveira@gmail.com (G.F.-O.); tiziana.fornari@uam.es (T.F.) \\ * Correspondence: b.hernandez@csic.es; Tel.: +34910017970
}

Citation: Franca-Oliveira, G.;

Fornari, T.; Hernández-Ledesma, B. A Review on the Extraction and

Processing of Natural Source-Derived

Proteins through Eco-Innovative

Approaches. Processes 2021, 9, 1626.

https://doi.org/10.3390/pr9091626

Received: 29 July 2021

Accepted: 3 September 2021

Published: 9 September 2021

Publisher's Note: MDPI stays neutral with regard to jurisdictional claims in published maps and institutional affiliations.

Copyright: (c) 2021 by the authors. Licensee MDPI, Basel, Switzerland. This article is an open access article distributed under the terms and conditions of the Creative Commons Attribution (CC BY) license (https:// creativecommons.org/licenses/by/ $4.0 /)$

\begin{abstract}
In addition to their nutritional and physiological role, proteins are recognized as the major compounds responsible for the rheological properties of food products and their stability during manufacture and storage. Furthermore, proteins have been shown to be source of bioactive peptides able to exert beneficial effects on human health. In recent years, scholarly interest has focused on the incorporation of high-quality proteins into the diet. This fact, together with the new trends of consumers directed to avoid the intake of animal proteins, has boosted the search for novel and sustainable protein sources and the development of suitable, cost-affordable, and environmentally friendly technologies to extract high concentrations of valuable proteins incorporated into food products and supplements. In this review, current data on emergent and promising methodologies applied for the extraction of proteins from natural sources are summarized. Moreover, the advantages and disadvantages of these novel methods, compared with conventional methods, are detailed. Additionally, this work describes the combination of these technologies with the enzymatic hydrolysis of extracted proteins as a powerful strategy for releasing bioactive peptides.
\end{abstract}

Keywords: food proteins; novel extraction methodologies; enzymatic hydrolysis; bioactive peptides

\section{Introduction}

Proteins are essential macronutrients involved in the growth and development of the body. In addition to their nutritional and physiological properties, the techno-functional characteristics of proteins are responsible for the appearance, texture, and stability of food products. Moreover, proteins have been demonstrated to be a source of peptides capable of exerting multiple biological activities after their release by hydrolysis, gastrointestinal digestion, and/or food processing [1].

The incorporation of high-quality proteins into the everyday diet is a prevalent theme in current research. To meet consumer trends in limiting the intake of animal proteins, nutritionists and food industries are exploring the use of novel and sustainable protein sources from plants, insects, and algae. However, satisfying this demand requires the simultaneous development of suitable, cost-effective, and eco-friendly technologies to extract higher concentrations of valuable proteins to be incorporated into food and supplements [2]. The application of conventional methods generally results in lower extraction yields due to protein degradation from extreme $\mathrm{pH}$, temperature, solvent conditions, and long extraction times. Therefore, researchers are currently focused on non-thermal green technologies for improving extraction efficiency and reducing protein degradation. These methods generally have no damaging effect on the environment. Moreover, the minimal use of toxic chemicals and reactants makes extracted proteins safe for animal and human consumption. Other than improving the protein yield, these innovative techniques can enhance their nutritional and techno-functional properties as well as their potential as a source of bioactive peptides. Understanding the principles of each of these new methodologies, and their advantages and disadvantages in comparison with conventional methods, is essential to advance in the knowledge of their applications in the food industry, and to 
achieve extractions, from new sources, of high-purity proteins with interesting properties at high concentrations. Thus, this review aims to respond to this need by providing all the existing evidence on the emergent extraction technologies applied on natural protein sources. Moreover, the application of some novel technologies, in combination with the enzymatic hydrolysis of extracted proteins with the aim to release bioactive peptides, is also described.

\section{Extraction of Proteins from Natural Sources}

\subsection{Chemical Extraction Techniques}

The classification of chemical methods is based on the solvent used, such as water, alkali, organic solvents, and acids. Although the efficiency of the methodology primarily depends on the nature of the protein sample, the processing conditions have also been demonstrated to show their influence on protein recovery [3]. Aqueous extraction is a frequently used method due to the high protein solubility and stability of isolated proteins in water. Moreover, this methodology shows other advantages such as its easy operation conditions and low cost [4]. Generally, extraction with water is performed under basic conditions, as it has been described for proteins from different plant sources such as mung bean (Vigna radiata) [5], grass pea (Lathyrus satious) [6], rice and rice bran [7,8], and tomato $[9,10]$, among others. However, extreme extraction conditions, such as high temperature or high alkaline conditions, could influence the thermal, conformational, and functional properties of protein fractions, reducing their nutritional value and degrading their bioactive compounds [11]. Mild acidic conditions have also been reported to efficiently extract proteins from sunflower with a 23-26\% rate recovery [12].

To extract proteins containing non-polar, hydrophobic and/or aromatic amino acid residues, organic solvents like ethanol, butanol, and acetone are required [13]. Thus, a recent study has described the application of an ethanol-petroleum ether combination in water to extract proteins from Moringa olifera seeds, reaching 33\% of recovery after the purification of the protein [4].

\subsubsection{Aqueous Two-Phase System (ATPS)}

Currently, aqueous two-phase system (ATPS) is being used for efficient protein extraction due to the associated properties, such as the hydrophobicity of the phase system, the electrical potential between phases, molecular size, and the bioaffinity of the protein [2]. ATPS is a multifunctional technique that allows separating, concentrating, and purifying proteins. It is based on the mixture of two components of different natures. The appropriate choice of these two components guarantees the completion of two defined and equilibrated layers. The benefits of the ATPS technique are of great interest to the scientific community. Its attributes of rapidity, flexibility, economical convenience, and biocompatibility ensure a higher selectivity, purity, and extraction yield than with conventional systems. On top of that, phase constituents do not denature proteins; they can stabilize protein structures within their biological activity [14]. A recent review summarizing the existing evidence on the application of ATPS for the recovery of valuables, as well as the elimination of contaminants from industrial waste discharges, has been published [15]. Among these high-value components, proteins have been demonstrated to be efficiently extracted by ATPS. Therefore, two-phase systems constituted by sodium citrate and polyethylene glycol, or sodium citrate and ethanol, have been recently reported as useful in extracting proteins from shrimp (Litopenaeus vannamei) waste and microalgae (Arthrospira platensis) [16,17].

\subsubsection{Subcritical Water Extraction (SWE)}

Subcritical water (SW) extraction (SWE) is a technique based on the use of hot water in the range from water's normal boiling point $\left(100^{\circ} \mathrm{C}\right)$ to water's critical temperature $\left(374^{\circ} \mathrm{C}\right)$, while using a high pressure to maintain water in its liquid state within those temperatures (usually 220-230 bar). The increase in temperature significantly modifies water's properties. For example, its viscosity and density decrease, but its compressibility remains low, and 
indeed the most important change is the temperature-dependent decrease of water's dielectric constant. Thus, the hydrogen bonding structure of water is weakened, which enables the solubilization of moderately polar and nonpolar compounds. Furthermore, SW produces a high-ion product, a property suitable for hydrolysis reactions and thus, when compared with water at lower temperatures and ambient pressures, SW conditions enhance the depolymerization of polysaccharides and the generation of smaller soluble protein fractions [18].

Mlyuka et al. [19] presented SWE as a strategic alternative for the food industry with promising potential in the selective extraction of bioactive compounds and in green hydrolysis reactions, while stressing scaling as the major challenge facing its commercial use. SWE is an efficient, cheap, fast, and environmentally friendly technology. Several reviews [19-21] analyzed the tuning of operation conditions in different types of raw materials, to maximize extraction yield and/or to avoid the degradation and decomposition of desired products. In general, in comparison with conventional alkali or enzymatic hydrolysis, SW provides comparable or higher yields in shorter times. In a very recent contribution, Álvarez-Viñas et al. (2021) reviewed the most important features in the SWE/hydrolysis of proteins, the different modes of operation, and analyzed the effect of process conditions on the product properties [22]. The authors highlighted the necessity of establishing optimal conditions as a compromised solution for processing proteins derived from agro-food wastes and algal biomass, suggesting that could be desirable in the stage wise operation to sequentially obtain high-valued fractions. Nevertheless, the formation of allergenic and/or toxic peptides from wastes and biomasses during protein extraction and hydrolysis should be prudently tested.

\subsection{Enzyme-Assisted Extraction}

Enzyme-assisted extraction (EAE) is a green technology based, firstly, on the action of degrading enzymes within the major components of the cell wall, such as cellulose, hemicellulose, and/or pectins, resulting in the disruption of the wall and the release of cellular proteins [23]. Secondly, proteases break down the high molecular weight cell proteins into smaller and more soluble portions, thus providing valuable extraction conditions [2]. Although EAE has been characterized by its long processing time, high costs, elevated energy consumption, and irreversible carbohydrate-protein matrix disruption, it has become an emergent strategy showing advantages in comparison with conventional solvent-based extraction methods [23]. Moreover, products obtained using this technology evidence a higher purity and suitability for human consumption [24-26]. Thus, Sari et al. demonstrated the higher protein yield resulting from the extraction of proteins from soybean (Glycine max) and rapeseed (Brassica napus subsp. napus) meals when serine, endo, and exoproteases were used in comparison to the protein yield obtained without enzyme addition [24]. Similarly, Rommi et al. [27] demonstrated the beneficial effects of pectinolytic enzymes acting on pectic polysaccharides and glucans on the extraction yield of proteins from rapeseed press cakes made from cold oil processing. The use of enzymes increased the protein yield by 1.7 times in comparison with that obtained without enzymes. In addition, these authors found that the enzymatic hydrolysis of carbohydrates at a $\mathrm{pH}$ of 6 allowed for the extraction of rapeseed press cake proteins with a higher solubility and dispersion stability than those obtained using an alkaline extraction that provoked their partial denaturation [28]. Chirinos et al. also found that the EAE (alcalase) of proteins from sacha inchi (Plukenetia volubilis L.) kernel meal resulted in a higher $(\approx 1.5$-fold) protein recovery than that obtained through alkaline extraction [29]. More recently, bi- $(\alpha-$ amylase and amyloglucosidase) and tri-enzyme ( $\alpha$-amylase, amyloglucosidase, and $\beta-1,3,4$ glucanase) treatments were applied to extract proteins from defatted barley flour, obtaining a protein yield of $49 \%$ and $78.3 \%$, respectively [30]. Similarly, defatted soybean flour was treated with xylanase, pectinase, cellulase, and a cocktail of commercial carbohydrases within alkaline extraction, resulting in the increase of the protein yield by $21 \%$ compared to the $2 \mathrm{~h}$ alkaline extraction without enzymatic treatment [31]. In a recent study, four 
enzyme preparations, followed by assisted alkaline extraction, were tested for protein extraction from the seaweed Palmaria palmata [32]. These authors found that the most efficient treatments were the combination of Celluclast ${ }^{\circledR} 0.2 \% w / w$ plus Alcalase ${ }^{\circledR} 0.2 \%$ $w / w\left(90.0 \%\right.$ extraction efficiency), or Shearzyme ${ }^{\circledR} 0.2 \% w / w$ plus Alcalase ${ }^{\circledR} 0.2 \% w / w$ ( $85.5 \%$ extraction efficiency). Moreover, these methods allowed for improving the amino acid profile, the essential amino acid score, and the ratio of the extracted proteins, in which their potential as source of bioactive peptides was also improved, making this methodology suitable for extracting proteins with interesting nutritional and functional properties. Recent studies have reported on the suitability of enzyme-assisted extraction to recover proteins from other sources, such as sugar beet (Beta vulgaris L.) leaves [33] and almond cake [34].

\subsection{Novel Assisting Cell Disruption Techniques}

\subsubsection{Microwave-Assisted Extraction (MAE)}

Microwave-assisted extraction (MAE) is a novel cell disruption technique that uses electromagnetic waves of frequency in the range from $300 \mathrm{MHz}$ to $300 \mathrm{GHz}$ [23]. These waves are absorbed by the matrix and converted into thermal energy, which heats the moisture inside the cells. This generates a high pressure on the cells' walls, increasing their porosity and thus facilitating the extraction of their compounds [35]. The main MAE parameters required for optimization and scaling up the extraction process are the sample solubility, the solid-liquid ratio, the extraction process time and temperature, the microwave power, the system agitation, the dielectric constant, and the dissipation factor [36-38]. In comparison with conventional technologies, MAE presents some advantages, such as a higher reproducibility in a shorter period of time, and a lower solvent and energy consumption. These advantages make MAE a suitable technology for extracting different compounds, such as proteins, carbohydrates, and antioxidant polyphenols [39]. Studies on the MAE of proteins from various biological sources are presented in Table 1. This Table shows a comparison of the yield values, protein content, and other characteristics of the resulting products with those obtained from traditional extraction technologies, such as solvent extraction or steam infusion, among others. According to these studies, the use of MAE results in higher plant protein yields compared to the standard alkaline procedure [26,40]. Electromagnetic microwaves also provide other potential advantages over conventional hydro-thermal treatments, such as uniform heating, an enhanced extraction rate, lower solvent consumption, and a higher extraction speed [3,41]. Moreover, the improvements of functional properties and the digestibility of extracted proteins when using MAE have been reported [26,42]. Thus, MAE has been recommended as an approach to extracting protein from structurally rigid biological samples, which are difficult to digest using enzymes and/or ultrasound waves, such as bran, or other by-products of the milling industry (i.e., sesame, rice, and wheat) [43-45].

\subsubsection{Ultrasound-Assisted Extraction (UAE)}

Although ultrasound-assisted extraction (UAE) has been studied since the 1950s as a suitable approach to obtain proteins from natural sources, its application in food science is very recent, being recognized as a clean and novel technology. UAE is based on the propagation of pressure oscillations in a liquid medium at the speed of sound, which results in the formation, growth, and collapse of microbubbles, allowing cell disruption and a mass transfer to the medium [46]. The bubbles generated are relatively large and their collapse provokes cell wall breakup, a reduction of in particle size, and a mass transfer across cell membranes, allowing the extraction of substances from the medium. UAE's performance is affected by different parameters, such as the food matrix, extraction solvent, exposure time and temperature, ultrasound frequency, power, amplitude, and the type of equipment used [47]. As a green technology, UAE is energy efficient, easy to install, with minimal environmental impact, and its maintenance costs are low. Moreover, it requires 
a low investment and shorter extraction times, thus reducing the process time and the associated costs [48].

Thus, as a fast, cost-effective, and environmentally friendly technology, UAE has been used to extract and modify vegetable proteins, improving the efficiency of the extraction process. Recently, the existing evidence for the UAE of plant-based protein has been summarized by Rahman et al. [47]. Moreover, comparison between UAE and conventional technologies used to extract proteins from vegetal and animal food sources is shown in Table 1. Ochoa-Rivas et al. compared alkali extraction, MAE, and UAE to extract protein from peanut flour. The highest protein yield resulted from UAE, which also improved the techno-functional properties (the water absorption, foaming and emulsifying activities) and the in vitro protein digestibility of the extracted proteins [26]. Furthermore, UAE was recently applied to extract individual arachin and conarachin from defatted peanut protein, resulting in an increase in the extraction yield, a shortening of the extraction time and temperature, and an improvement of the emulsifying properties of arachin [49]. Similarly, increases in the protein yield and the enhancement of the functional and biological properties were reported after the UAE of proteins from pea and brewer's spent grain proteins $[50,51]$. Although the number of studies applying UAE to extract proteins from animal sources is more limited, this technology has been also recognized as a means to increase the extraction yield and improve the functional properties of extracted proteins from chicken liver and common carp (Cyprinus carpio) byproducts [52,53].

Despite being considered a novel and suitable approach to extracting proteins from different food materials, UAE has been associated with some weaknesses, such as the formation of radicals responsible for the release of degradation products affecting protein quality, resulting in protein oxidation, loss of aroma, changes in protein color, structure changes, texture alterations, free radical formation, and a metallic flavor [54].

Table 1. Comparison between conventional and emergent assisting cell disruption technologies (microwave and ultrasoundassisted) for the extraction of food proteins.

\begin{tabular}{|c|c|c|c|c|}
\hline \multirow[b]{2}{*}{ Food Protein Source } & \multicolumn{3}{|c|}{ Results of the Extraction Process } & \multirow[b]{2}{*}{ Reference } \\
\hline & $\begin{array}{l}\text { Conventional } \\
\text { Extraction }\end{array}$ & Microwave-Assisted & Ultrasound-Assisted & \\
\hline \multirow[t]{2}{*}{ Rice bran } & $\begin{array}{l}\text { Extraction yield: } \\
\quad 12.85 \% \\
\text { Protein content: } 75.32 \% \\
\text { Extraction time: } 60 \mathrm{~min}\end{array}$ & $\begin{array}{l}\text { Extraction yield: } \\
\quad 15.68 \% \\
\text { Protein content: } 79.98 \% \\
\text { Extraction time: } 2 \mathrm{~min}\end{array}$ & & [41] \\
\hline & Protein yield: $2.92 \%$ & $\begin{array}{c}\text { Protein yield: } 4.37 \% \\
\text { Protein content: } 71.27 \%\end{array}$ & & [40] \\
\hline Rice & $\begin{array}{l}\text { Extraction yield: } 38.0 \% \\
\text { Protein purity: } 64.12 \%\end{array}$ & & $\begin{array}{c}\text { Extraction yield: } 65.0-86.0 \% \\
\text { (combined with } \alpha \text {-amylase } \\
\text { degradation) } \\
\text { Protein purity: } 77.47-92.99 \% \\
\text { Higher solubility, emulsifying activity } \\
\text { and foaming capacity }\end{array}$ & [55] \\
\hline \multirow[t]{2}{*}{ Sesame bran } & $\begin{array}{l}\text { Protein content: } 24.5 \% \\
\text { TPC: } 3.45 \text { mg GAE/g }\end{array}$ & $\begin{array}{l}\text { Protein content: } 43.8 \text { to } \\
61.6 \% \text { ( } 91.7 \% \text { by MAEE) } \\
\text { TPC: } 4.20 \mathrm{mg} \text { GAE/g } \\
\text { (8.04 mg GAE/g by } \\
\text { MAEE) } \\
\text { Highest recovery of } \\
\text { antioxidant compounds }\end{array}$ & & [44] \\
\hline & $\begin{array}{l}\text { Protein yield: } 24.5 \% \\
\text { (alkaline } \\
\text { extraction)-79.3\% } \\
\text { (enzymatic-assisted } \\
\text { extraction) }\end{array}$ & & $\begin{array}{c}\text { Protein yield: } 59.8 \\
\text { (ultrasound-assisted)-87.9\% } \\
\text { (combined with enzymatic treatment) }\end{array}$ & {$[45]$} \\
\hline
\end{tabular}


Table 1. Cont

\begin{tabular}{|c|c|c|c|c|}
\hline \multirow[b]{2}{*}{ Food Protein Source } & \multicolumn{3}{|c|}{ Results of the Extraction Process } & \multirow[b]{2}{*}{ Reference } \\
\hline & $\begin{array}{l}\text { Conventional } \\
\text { Extraction }\end{array}$ & Microwave-Assisted & Ultrasound-Assisted & \\
\hline & & & $\begin{array}{c}\text { Protein yield: } 58.0 \% \\
\text { (vacuum-ultrasound assisted)-65.9\% } \\
\text { (vacuum-ultrasound assisted } \\
\text { enzymatic extraction) } \\
\text { Higher total phenolic capacity and } \\
\text { antioxidant capacity }\end{array}$ & {$[56]$} \\
\hline Peanut flour & Protein yield: $42.4 \%$ & $\begin{array}{l}\text { Protein yield: } 55.0 \% \\
\text { Improvement of water } \\
\text { absorption, foam } \\
\text { activity, emulsifying } \\
\text { activity, and in vitro } \\
\text { digestibility }\end{array}$ & $\begin{array}{l}\text { Protein yield: } 57.6 \% \\
\text { Improvement of water absorption, } \\
\text { foam activity, emulsifying activity, and } \\
\text { in vitro digestibility }\end{array}$ & {$[26]$} \\
\hline $\begin{array}{c}\text { Defatted peanut } \\
\text { protein }\end{array}$ & & & $\begin{array}{c}\text { Arachin extraction yield: } 37.53 \% \\
\text { Conarachin extraction yield: } 7.57 \% \\
\text { Shortening of the extraction time and } \\
\text { temperature } \\
\text { Improvement of emulsifying } \\
\text { properties of arachin }\end{array}$ & {$[49]$} \\
\hline $\begin{array}{l}\text { Defatted wheat germ } \\
\text { protein }\end{array}$ & $\begin{array}{l}\text { Extraction yield: } \\
\text { 24.0-37.0\% }\end{array}$ & $\begin{array}{c}\text { Extraction yield: } 45.6 \% \\
\text { (combined with reverse } \\
\text { micelles) }\end{array}$ & & {$[43]$} \\
\hline Pea protein & Extraction yield: $71.6 \%$ & & $\begin{array}{l}\text { Extraction yield: } 82.6 \% \\
\text { Shortening of extraction times and } \\
\text { reduction of water consumption } \\
\text { Improvement of functional properties } \\
\text { and biological activities }\end{array}$ & {$[50]$} \\
\hline Alfalfa protein & & & $\begin{array}{c}\text { Extraction yield: } 14.5 \% \\
\text { (Ultrasound-ultrafiltration-assisted } \\
\text { alkaline ioelectric precipitation) } \\
\text { Potein content: } 91.1 \mathrm{~g} / 100 \mathrm{~g} \\
\text { Increase of solubility, water-holding } \\
\text { and oil-binding capacities } \\
\text { Reduction of emulsifying and foaming } \\
\text { properties }\end{array}$ & {$[51]$} \\
\hline $\begin{array}{l}\text { Brewer's spent grain } \\
\text { protein }\end{array}$ & $\begin{array}{l}\text { Extraction yield: } \\
45.71 \%\end{array}$ & & $\begin{array}{c}\text { Extraction yield: } 86.16 \% \\
\text { Protein purity: } 57.84 \% \\
\text { Enhancement of the fat absorption } \\
\text { capacity, emulsifying and foaming } \\
\text { properties }\end{array}$ & {$[57]$} \\
\hline Soy milk & $\begin{array}{l}\text { Extraction yield: } 3.86 \% \\
\quad \text { (steam infusion) } \\
\text { Protein content: } 7.38 \%\end{array}$ & $\begin{array}{l}\text { Extraction yield: } 4.83 \% \\
\text { Protein content } 13.12 \% \\
\text { Improvement of } \\
\text { characteristics of soy } \\
\text { milk } \\
\text { Increase of protein } \\
\text { solubility and } \\
\text { digestibility }\end{array}$ & & {$[58]$} \\
\hline Soy okra & $\begin{array}{l}\text { Extraction yield: } 0.35 \% \\
\quad \text { (steam infusion) } \\
\text { Protein content: } 25.0 \%\end{array}$ & $\begin{array}{l}\text { Extraction yield: } 0.23 \% \\
\text { Protein content } 18.5 \%\end{array}$ & & {$[58]$} \\
\hline $\begin{array}{c}\text { Jackfruit } \\
\text { leaves }\end{array}$ & Protein content: 8.41\% & Protein content: $9.56 \%$ & Protein content: $9.63 \%$ & {$[59]$} \\
\hline
\end{tabular}


Table 1. Cont.

\begin{tabular}{|c|c|c|c|c|}
\hline \multirow[b]{2}{*}{ Food Protein Source } & \multicolumn{3}{|c|}{ Results of the Extraction Process } & \multirow[b]{2}{*}{ Reference } \\
\hline & $\begin{array}{l}\text { Conventional } \\
\text { Extraction }\end{array}$ & Microwave-Assisted & Ultrasound-Assisted & \\
\hline $\begin{array}{l}\text { Eurycoma longifolia } \\
\text { roots }\end{array}$ & $\begin{array}{l}\text { Extraction yield: } 9.76 \% \\
\text { in } 38 \text { min (heat } \\
\text { assisted) }\end{array}$ & & Extraction yield: $9.54 \%$ in 5 min & [60] \\
\hline Coffee silverskin & $\begin{array}{c}\text { Protein yield: } 24.35 \% \\
\text { (alkali } \\
\text { extraction)-32.52\% } \\
\text { (sequential } \\
\text { alkaline-acid } \\
\text { extraction) }\end{array}$ & Protein yield: $43.53 \%$ & Protein yield: $14.04 \%$ & [61] \\
\hline $\begin{array}{l}\text { Dolichos lablab L. } \\
\text { protein }\end{array}$ & $\begin{array}{l}\text { Extraction yield: } \\
40.95 \%\end{array}$ & & $\begin{array}{c}\text { Extraction yield: } 69.98 \% \\
\text { Enhancement of functional } \\
\text { characteristics and antioxidant } \\
\text { capacity of the protein }\end{array}$ & [62] \\
\hline $\begin{array}{l}\text { Common carp } \\
\text { by-products }\end{array}$ & & $\begin{array}{c}\text { Extraction yield: } \\
0.82-1.27 \% \\
\text { Protein content: } 87.63 \\
\text { to } 88.19 \% \\
\text { Reverse correlation } \\
\text { between the extraction } \\
\text { time and the gel } \\
\text { strength and viscosity } \\
\text { of gelatin }\end{array}$ & $\begin{array}{l}\text { Extraction yield: } 19.80-27.0 \% \\
\text { Protein content: } 86.15 \text { to } 90.21 \% \\
\text { Decrease of the gel strength and } \\
\text { viscosity of gelatin }\end{array}$ & [53] \\
\hline Duck feet gelatin & $\begin{array}{l}\text { Extraction yield: } \\
51.83 \% \text { (water bath) } \\
\text { and } 22.06 \% \text { (electric } \\
\text { pressure cooker) }\end{array}$ & $\begin{array}{c}\text { Extraction yield: } \\
17.58 \% \\
\text { Improvement of gel } \\
\text { strength, melting point, } \\
\text { and viscosity }\end{array}$ & & [42] \\
\hline Bighead carp & $\begin{array}{c}\text { Protein yield: } \\
\text { 19.15-36.39\% (water } \\
\text { bath) } \\
\text { Protein content: } \\
84.15-88.67 \%\end{array}$ & $\begin{array}{l}\text { Protein yield: } \\
\text { 30.94-46.67\% } \\
\text { Protein content: } \\
89.17-91.85 \%\end{array}$ & & [63] \\
\hline Chicken liver protein & $\begin{array}{l}\text { Extraction yield: } 43.5 \% \\
\text { Protein content: } 63.9 \%\end{array}$ & & $\begin{array}{c}\text { Extraction yield: } 67.6 \% \\
\text { Protein content: } 61.8 \% \\
\text { Improvement of the water/oil holding } \\
\text { capacity and emulsifying properties }\end{array}$ & [52] \\
\hline
\end{tabular}

TPC: total phenolic content; GAE: gallic acid equivalent; MAEE: Microwave-assisted enzymatic extraction.

In addition, when UAE is applied at high intensities, it generates heat which provokes protein denaturation and unfolding. Thus, the intensity and synergy of ultrasound need to be optimized before their application. Recently, UAE has been combined with other technologies to reduce its limitations and improve the extraction of food proteins. Among these combinations, those including UAE and EAE have been reported to be effective to extract target compounds with the advantages of enhanced extraction yield, reduced extraction time, and physiological activity. Görgüç et al. compared alkali-EAE with ultrasound-EAE, reporting an increase in the sesame bran protein yield from $79.3 \%$ to $87.9 \%$ [45]. These authors also found an increase in the protein yield, phenolic content, and antioxidant capacity of the protein extracts when vacuum-ultrasound-EAE was applied to the sesame bran [56]. 


\subsubsection{Pulsed Electric Field and High Voltage Electrical Discharge Extraction}

Pulsed electric field (PEF) and high voltage electrical discharge (HVED) are emerging non-thermal technologies that use high voltage to generate an electric field to perform an extraction. Both technologies are based on the pores formed on the cell membrane (electroporation) resulting from the application of an electric field, thus allowing the extraction of intracellular components through a diffusion process [64]. In PEF technology, a material is placed between two electrodes through which high voltage pulses (from 100 to $300 \mathrm{~V} / \mathrm{cm}$ to $20-80 \mathrm{kV} / \mathrm{cm}$ ) are applied in short time periods. Under the effect of PEF, the cell membrane is electrically pierced, losing its permeability in a reversible or irreversible manner depending on the electrical parameters, the cell characteristics (size, age, and shape), and the pulsing media composition [65]. These features have made PEF into an extensive technology for microorganisms' inactivation, recovering high-value compounds, like proteins and polyphenols, and improving freezing and drying processes [66]. In HVED technology, a current of high-voltage electrical discharge is applied between two electrodes forming a plasma channel where energy is then presented directly in a liquid. Because PEF and HVED are non-thermal techniques, they present some advantages over conventional heat-assisted extraction techniques, such as their ability to preserve thermolabile food constituents as proteins and increasing the quality of the extracts during processing and throughout the storage period [13]. Moreover, the low energy consumption of these extraction processes agrees with the principles of green extraction [67].

Recent studies have applied PEF and HVED to recover proteins from different natural sources. For example, Roselló-Soto et al. compared the effects of PEF, HVED, and ultrasound pre-treatments before the extraction of intracellular compounds from olive kernels [68]. In this study, HVED technology was found to be more effective than others in terms of the energy and treatment time required to extract the phenolic compounds and proteins. Sarkis et al. also reported on the efficiency of the PEF and HVED approaches in increasing the yield of polyphenol, lignin, and protein extracts from sesame cake, and in improving the kinetics of diffusion [69]. More recently, PEF technology was applied to release and extract proteins from the microalgae Chlorella vulgaris and Neochloris oleoabundans. The protein yield was much lower than that obtained using mechanical approaches with a higher energy input [70]. Although PEF technology has been associated with changes in the solubility and functional properties of extracted proteins, these modifications can be beneficial. Thus, Zhang et al. reported that the PEF treatment of canola (Brassica napus) seeds increases the solubility, emulsifying, and foaming properties of the extracted proteins [71]. Changes in the secondary structure and in the antioxidant activity of peptides released from pine nut proteins have also been reported [72].

\subsubsection{High Hydrostatic Pressure-Assisted Extraction}

High hydrostatic pressure (HHP) technology is based on the application of an isostatic pressure ranging from 100 to $1000 \mathrm{MPa}$ transmitted instantaneously and uniformly through a fluid, generally water. This pressure provokes the deformation of cells and the damage of their membranes and protein structures, thus allowing for the penetration of the solvent within cells and increasing the transfer rate of its intracellular components [73]. HHP processing, also known as "cold pasteurization", has been traditionally used in the food industry to reduce the microbial charge and improve the shelf-life of different food systems [74]. However, in recent years, HHP processing has been extended to other innovative uses, such as the selective recovery of phenolic compounds, polysaccharides, fats, and proteins, among others [75-77]. Moreover, HHP processing has become one of the most efficient methods for modifying the properties of proteins, such as thermal and rheological properties, gelation solubility, water holding and foaming capacity, stability, surface hydrophobicity, emulsifying activity, and stability [78]. It also induces the reversible denaturation of native proteins and the modulation of protein-protein and protein-solvent interactions, stimulating the formation of oligomeric and aggregated species that can negatively affect the digestibility of the protein $[79,80]$. However, in some cases, the alteration 
of the food proteins profile caused by HHP results in the higher exposure of susceptible digestion sites and, consequently, in a higher hydrolysis and yield of hydrolytic products, thereby reducing both time and costs [81]. In addition to its ability to modify proteins, HHP also shows an ability to modulate the conformation and activity of different enzymes as well as their interaction with their target proteins [82]. Additionally, in the recent years HHP has been employed in combination with enzymatic treatments to hydrolyze proteins from different food sources, such as kidney and pinto bean (Phaseolus vulgaris), soy and flaxseed (Linum usitatissimum) protein, and whey protein isolate, and to release bioactive peptides (see the review of Ulug et al. [83]). Since the efficiency of hydrolysis depends on the protein system, pressurization conditions, and the enzyme used, optimizing these parameters to produce the maximum amount of bioactive peptides from a complex food matrix is essential to accelerate the development of bioactive peptides-based food products.

\section{Release of Bioactive Peptides}

Bioactive peptides are sequences of amino acids inactive within the source protein. Once released, they can exert antioxidant, anti-inflammatory, antihypertensive, anti-obesity, antimicrobial, and immunomodulatory biological activities. These activities suggest their potential as novel, safe, and effective ingredients for functional foods and/or nutraceuticals to prevent and manage chronic disorders. Enzymatic hydrolysis and fermentation are the most known conventional methods to release bioactive peptides from their source protein. However, their use in the food industry is limited due to some disadvantages. Acid and alkaline hydrolysis are low-cost methodologies, but they affect some amino acid residues, thus resulting in the loss of nutritional and biological value of the released peptides [8]. Enzymatic proteolysis is a better alternative for hydrolyzing proteins due to the enzyme's specificity, but it can be expensive, time consuming, and require the use of acids and bases for $\mathrm{pH}$ control [84]. In the case of fermentation, it offers the advantage of removing hyper-allergic or antinutritional factors, but the costs are also relatively high [8]. Moreover, to produce protein hydrolyzates and bioactive peptides, efficient and scalable methods should be used to avoid the use of harmful chemicals and solvents, costly enzymes, and long processing times [21]. Therefore, in recent years, novel technologies such as ultrasounds, microwave-assisted processing, HHP, PEF, and SW hydrolysis are being explored to enhance the production of bioactive peptides [83] (Figure 1).

In addition to extracting proteins, microwave radiation is capable of improving proteolysis and releasing low molecular weight peptides when combined with enzymatic hydrolysis, thereby increasing the bioactivities of the resultant hydrolyzates. Thus, in comparison to thermal processing, MA-hydrolysis has significantly increased the dipeptidyl peptidase IV (DPP-IV) and ACE inhibitory activities of cricket (Gryllodes sigillatus) protein hydrolyzates [85], and the antioxidant capacity of chia (Salvia hispanica) protein hydrolyzates [86]. Similarly, this combination has been used to prepare bioactive peptides from bovine serum albumin, ginkgo (Ginkgo biloba) nuts [87], milk protein concentrate [88], bighead carp (Aristichthys nobilis) [89], fish protein [90], trout frame (Oncorhynchus mykiss) [91], and collagen sea cucumber (Acaudina molpadioides) [92]. Microwave radiation facilitates the exposure of cleavage sites of the protein to the enzyme action; thus, the hydrolysis efficiency, processing time, and reproducibility are generally improved by this technology. Other advantages of microwave processing over conventional methods include its simple handling and low cost [93]. 


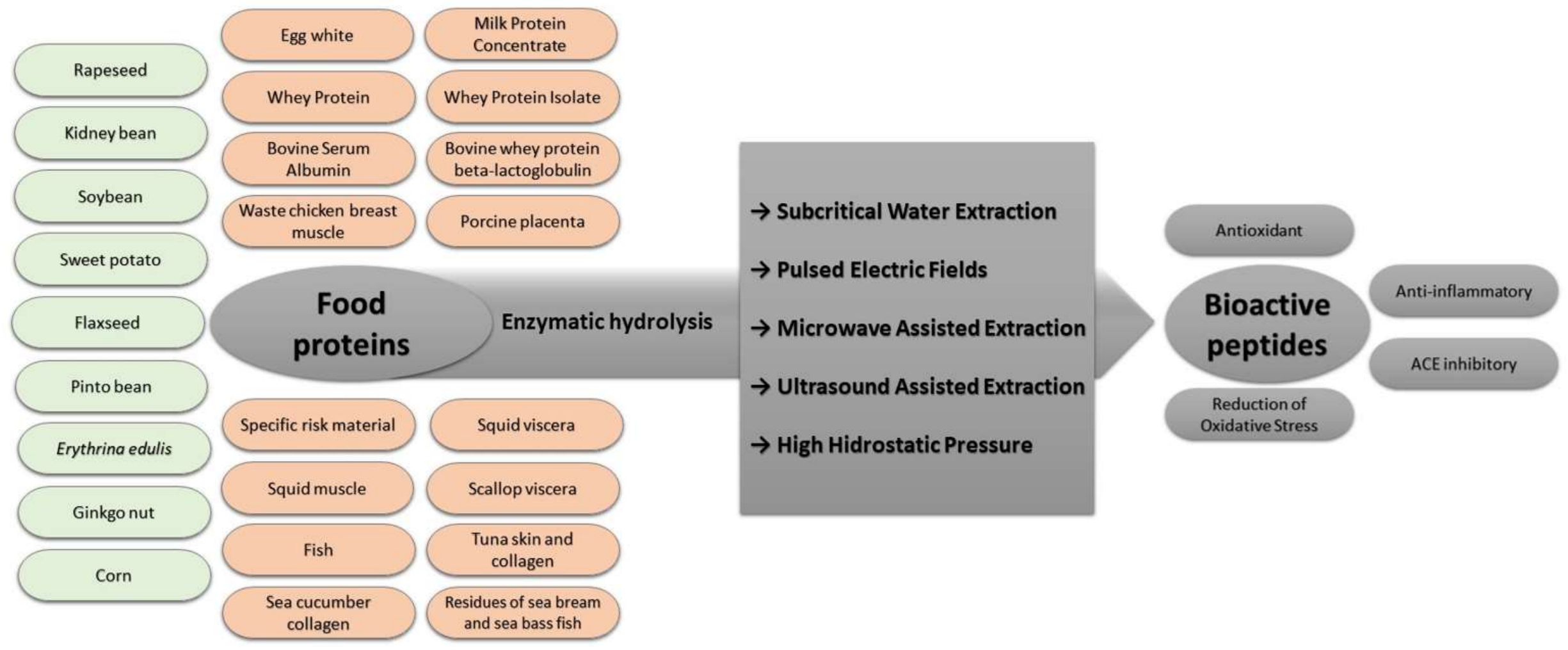

Figure 1. Hydrolysis of food sources assisted by novel and green technologies to release bioactive peptides. 
Although the application of ultrasounds alone is not enough to break peptidic bonds, this technology is capable of increasing the ability for enzymes into enter peptide bonds; thus, its combination with enzymatic hydrolysis is recognized as a suitable means to improve the production of bioactive peptides. This combination also shows other advantages over conventional hydrolysis, such as a speedier energy and mass transfer, diminished temperature and time, a higher process control, and a higher selectivity of the extraction [39]. Several food proteins have been used as a source of bioactive peptides following the application of UA-hydrolysis. Thus, more potent ACE inhibitory [94] and antioxidant [95] peptides were released after applying an ultrasound step before hydrolysis of wheat protein. More recently, the improvement of the ACE inhibitory activity of rapeseed protein hydrolyzates has been demonstrated [96]. Ultrasound has also been employed to increase the bioactivities of hydrolyzates from animal proteins such as milk and whey protein [88,97] and ovotransferrin [98].

HHP is another green technology employed to increase the production process of bioactive peptides due to its ability to denature protein and improve the accessibility of enzymes within susceptible cleavage sites [83]. Within the animal kingdom, HHPassisted enzymatic hydrolysis has been applied to whey protein isolate [99] and betalactoglobulin [100] to release bioactive peptides. Similarly, this technology has been employed to produce bioactive hydrolyzates from pinto beans [101], kidney beans [102], soy protein [103], and flaxseed protein [104].

Because of its ability to break non-covalent bonds, such as hydrogen bonds, hydrophobic interactions, and covalent bonds, PEF is considered as an environmentally friendly choice for producing antioxidant extracts from food byproducts, such as fish heads, bones, and gills [105]. PEF has also been recognized as useful for hydrolyzing food proteins, such as egg white proteins [106-108] and soybean proteins [109], resulting in the release of small weight antioxidant peptides. Although this methodology shows some advantages over conventional hydrolysis, such as shorter treatment times and lesser energy consumption, its current use is still limited due to its' high investment costs [110].

SW-hydrolysis (SWH) is a clean and fast protein hydrolysis alternative to acid, alkali, and enzymatic hydrolysis methods. It implies the application of high pressure to maintain water in its liquid state at temperatures above its boiling point. The high temperature results in high diffusion, low viscosity, and low surface tension, allowing the hydrolysis of proteins in shorter times [111]. Thus, because of its non-toxic and non-flammable attributes, SWH has been used in recovering a large variety of high value-added bioactive protein hydrolyzates and peptides from different animal and vegetable sources (Table 2). Despite the fact that SWH can be applied as a pre-treatment process before enzymatic hydrolysis to improve the biological activities of food proteins [112], it can also be used without using enzymes, thus reducing the process time and costs and avoiding the use of hazardous solvents and chemicals [113]. However, some disadvantages, such as high infrastructure costs and the necessity to optimize multiple process conditions to increase the efficiency of $\mathrm{SWH}$, limit the current application of this methodology [83].

\section{Supercritical $\mathrm{CO}_{2}$ in Protein Extraction and Processing}

Supercritical carbon dioxide $\left(\mathrm{SC}-\mathrm{CO}_{2}\right)$ has opened a wide range of new alternatives in food technology. Many studies and applications of $\mathrm{SC}-\mathrm{CO}_{2}$ in the processing of certain target food components, such as oils, fatty acids, phytosterols, alkaloids, carotenoids, and flavonoids, were widely reported in the last few decades. Proteins were not the exception, despite the complexity of their structure and properties. Several applications of SC- $\mathrm{CO}_{2}$ in protein processing are related with the elimination of oils and other lipophilic substances from protein-based matrices, such as the recent works reported by different authors [114-116]. In these works, the supercritical step is just a pre-treatment and the $\mathrm{SC}-\mathrm{CO}_{2}$ is used as an extractive solvent to eliminate the oily substances prior to the protein isolation from the food matrix (canola seeds, quinoa seeds and corn germ, respectively). 
Besides extraction, $\mathrm{SC}-\mathrm{CO}_{2}$ can be applied in other protein-based processes, such as the precipitation of protein particles, the separation of peptides, or the improvement of protein functionalities taking into advantage the structural and conformational modifications that can be attained by their exposure to high pressure $\mathrm{CO}_{2}$.

Table 2. Subcritical water assisted hydrolysis of natural proteins to release bioactive hydrolyzates and peptides.

\begin{tabular}{ll}
\hline \multicolumn{1}{c}{ Natural Source } & \multicolumn{1}{c}{ Hydrolysis Conditions } \\
\hline \multirow{3}{*}{ Whey protein isolate (WPI) } & $\begin{array}{l}\text { WPI:water ratio }=60 \mathrm{~g} / \mathrm{L} \\
\text { Different temperatures and times } \\
\text { (experimental design) }\end{array}$ \\
\hline \multirow{3}{*}{ Bovine seroalbumin } & $\begin{array}{l}\text { Seroalbumin:water ratio }=10 \\
\mathrm{mg} / \mathrm{mL} \\
\text { Different temperatures and times }\end{array}$ \\
\hline
\end{tabular}

Hemoglobin, bovine seroalbumin, and $\beta$-casein
Protein: water ratio $=1 \mathrm{mg} / \mathrm{mL}$

Different temperatures and times

\begin{tabular}{|c|c|}
\hline Results & Reference \\
\hline $\begin{array}{l}\text { ffective and fast }(<60 \mathrm{~min} \text { ) WPI hydrolysis } \\
\text { Jeneration to the highest total amino acid } \\
\text { nd lysine concentration at } 300{ }^{\circ} \mathrm{C} \text { for } 40 \mathrm{~min}\end{array}$ & [84] \\
\hline $\begin{array}{l}\text { Sreatest release of free amino groups and } \\
\text { naximum amount of amino acids at } 280{ }^{\circ} \mathrm{C} \\
\text { High generation of alanine and glycine }\end{array}$ & [117] \\
\hline $\begin{array}{l}\text { High protein sequence coverages }(>80 \%) \\
\text { omparable to those obtained by trypsin } \\
\text { ligestion } \\
\text { Favored cleavage of the Asp-X bond under } \\
\text { nild conditions }\left(160^{\circ} \mathrm{C}\right) \text { for three proteins } \\
\text { Tavored cleavage of the Glu-X bond under } \\
60^{\circ} \mathrm{C} \text { and } 207^{\circ} \mathrm{C} \text { ( } \beta \text {-casein) and } 207^{\circ} \mathrm{C} \\
\text { seroalbumin) }\end{array}$ & [118] \\
\hline
\end{tabular}

Highest degree of hydrolysis at $140{ }^{\circ} \mathrm{C}$ for 5

min

Scomber japonicus muscle protein

Different temperatures
Highest antioxidant activity at $140{ }^{\circ} \mathrm{C}$ for 5

$\mathrm{min}$ and tyrosinase inhibitory activity at 200 ${ }^{\circ} \mathrm{C}$ for $15 \mathrm{~min}$
Release of small and potent antioxidant peptides

Hydrolysis time $=3 \mathrm{~min}$

Bacterial collagenolytic protease-extracted collagen:solvent ratio $=1: 200(w: v)$

Hydrolysis time $=3 \mathrm{~min}$

Sample:liquid ratio = 1:200

(collagen) and 1:50 (skin)

Different temperatures

Hydrolysis time $=5 \mathrm{~min}$

Tuna skin collagen and skin

Different temperatures Hydrolysis time $=30 \mathrm{~min}$

Atlantic cod (Gadus morhua) frames

Powder:water ratio $=30 \mathrm{~g} / \mathrm{L}$

Different temperatures

Hydrolysis time $=15 \mathrm{~min}$

Efficient hydrolysis of collagen

Release of small ( $<425 \mathrm{Da})$ and potent

antioxidant and antimicrobial peptides

Highest antioxidant and antimicrobial activity at $280^{\circ} \mathrm{C}$

Release of low molecular weight peptides

( $<600 \mathrm{Da}$ ) and/or free amino acids associated with the bioactivity

Release of smaller peptides at high

temperatures $\left(250^{\circ} \mathrm{C}\right)$

Potent anti-inflammatory potential of

hydrolyzates in Caco-2 cells

Release of small (<1000 Da) peptides at temperature higher than $200^{\circ} \mathrm{C}$

Release of antioxidant and anti-hypertensive peptides

Efficient protein extraction as starting

Algae:seawater ratio $=8 \%(w: w)$

Hydrolysis time $=40 \mathrm{~min}$

material for fermentation with E. coli and $S$. cerevisiae

Powder:water ratio $=1: 20(w: v)$

Algae Laver (Pyropia yezoensis) Different temperatures

Hydrolysis time $=30 \mathrm{~min}$

Extraction of the maximum amount of amino acids at $120^{\circ} \mathrm{C}$

Extraction of potent antioxidant compounds

Highest amino group content and yield at $190^{\circ} \mathrm{C}$

Influence of the temperature on color

parameters

Release of small peptides

Inhibitory effects on murine macrophages

viability 


\subsection{Precipitation of Micro and Nano Protein Particles}

Several SC- $\mathrm{CO}_{2}$ techniques are currently available for particle formation, encapsulation and the drying of a wide type of materials, indicating the flexibility of $\mathrm{SC}-\mathrm{CO}_{2}$ technology which offers worthy advantages, such as the control of the particle size, size distribution, and morphology, in comparison with conventional technologies (spry-drying, jet milling, freeze drying, and coacervation). Food lipids, carbohydrates, proteins, and minor components have been processed using these $\mathrm{SC}-\mathrm{CO}_{2}$ techniques with the major purpose to deliver bioactive components.

Table 3 shows several protein-based $\mathrm{SC}-\mathrm{CO}_{2}$ processes reported in the literature, categorized according to the overall objective of the supercritical approach, i.e., the formation of micro/nanoparticles and the use of $\mathrm{SC}-\mathrm{CO}_{2}$ for drying and atomization.

Table 3. Examples of protein-based ingredients obtained using pressurized fluid technologies.

\begin{tabular}{|c|c|c|c|}
\hline Protein & $\mathrm{SC}-\mathrm{CO}_{2}$ Technique & Abbreviation & Reference \\
\hline \multicolumn{4}{|c|}{ Particle formation } \\
\hline Lysozime & Precipitation with a Compressed fluid Antisolvent & PCA & [127] \\
\hline Lysozime & Solution Enhanced Dispersion of Solids & SEDS & [128] \\
\hline Whey protein isolate (WPI) & Gas Anti-Solvent & GAS & [129] \\
\hline Bovine serum albumin (BSA) & Particles from Gas Saturated Solutions & PGSS & [130] \\
\hline Zein & Supercritical Anti-Solvent & SAS & [131] \\
\hline Lysozime & Supercritical Fluid Extraction of Emulsions & SFEE & [132] \\
\hline \multicolumn{4}{|c|}{ SC-CO ${ }_{2}$-assisted drying and atomization } \\
\hline Gelatin & Particles from Gas Saturated Solutions for drying & PGSS drying & [133] \\
\hline Lysozime + sugars & Particles from Gas Saturated Solutions for drying & PGSS drying & {$[134]$} \\
\hline Lysozime & Expanded Liquid Anti-Solvent & ELAS & {$[135]$} \\
\hline Bovine serum albumin (BSA) & Expanded Liquid Anti-Solvent & ELAS & {$[136]$} \\
\hline Lysozime & Supercritical Assisted Atomization & SAA & {$[137]$} \\
\hline Bovine serum albumin (BSA) & $\begin{array}{l}\text { Supercritical Assisted Atomization with Hydrodynamic } \\
\text { Cavitation Mixer }\end{array}$ & SAA-HCM & [138] \\
\hline Lysozime & $\begin{array}{l}\text { Supercritical Assisted Atomization with Hydrodynamic } \\
\text { Cavitation Mixer }\end{array}$ & SAA-HCM & [139] \\
\hline Trypsin and trypsin-chitosan & $\begin{array}{l}\text { Supercritical Assisted Atomization with Hydrodynamic } \\
\text { Cavitation Mixer }\end{array}$ & SAA-HCM & [140] \\
\hline \multicolumn{4}{|l|}{$\mathrm{SC}-\mathrm{CO}_{2}$-assisted impregnation } \\
\hline Bovine haemoglobin $(\mathrm{bHb})$ & Supercritical Solvent-Assisted Impregnation & SSI & [141] \\
\hline Soy protein & Supercritical Solvent-Assisted Impregnation & SSI & [142] \\
\hline
\end{tabular}

$\mathrm{SC}-\mathrm{CO}_{2}$ techniques using solvents such as dimethyl sulfoxide (DMSO) contradicts the main advantage of this technology for food applications. For example, Moshashaée et al. determined $20 \mathrm{ppm}$ of residual DMSO solvent in the Solution Enhanced Dispersion of Solids (SEDS) precipitation of lysozyme [128]. The challenge is circumventing the use of solvents or limiting their use to food-grade solvents. This is the case of the friendly whey protein fractionation process developed by Yver et al. to produce enriched fractions of $\alpha$-lactalbumin ( $\alpha$-LA) and $\beta$-lactoglobulin $(\beta-\mathrm{LG})$ from a commercial whey protein isolate (WPI) [129]. SC- $\mathrm{CO}_{2}$ was injected into the vessel containing the WPI de-ionized water solution, and the $\mathrm{pH}$ modification produced due to the $\mathrm{SC}-\mathrm{CO}_{2}$ dissolution allowed the fractionation of the proteins. A solid $\alpha$-LA-enriched phase was selectively precipitated at $\mathrm{pH}$ 4.4-5.0 and separated from the liquid $\beta$-LG-enriched fraction. After the supercritical treatment, these fractions were ready-to-use and did not contain salt, acid, or other chemical 
contaminants. The highest $\alpha$-LA purity was $61 \%$ ( $\alpha$-LA initial concentration in WPI was $18 \%$ ) with $80 \%$ of $\alpha$-LA recovery in the solid fraction, and was obtained at $60{ }^{\circ} \mathrm{C}, 83 \mathrm{bar}$ and $5 \%$ of proteins in WPI. Lima et al. described a continuous flow reactor for the protein fractionation process, testing pressures in the range of 80-240 bar and temperatures of 55-65 ${ }^{\circ} \mathrm{C}$ [143]. The initial ratio $\alpha$-LA/ $\beta$-LG in the WPI was 1:2.7 and the combination 80 bar and $55^{\circ} \mathrm{C}$ was found to be the best condition to obtain $\alpha$-LA ( $\alpha$-LA/ $\beta$-LG $=3.84$ and $20.9 \%$ precipitation yield). These process conditions also resulted in a $\beta$-LG-enriched fraction. Recently, the authors reported a techno-economic assessment of this continuous $\alpha$-LA/ $\beta$-LG supercritical fractionation [144].

Other remarkable reports concerning the protein particle formation using $\mathrm{SC}-\mathrm{CO}_{2}$ technique are those published by Perinelli et al., Zhong et al., and Kluge et al. [130-132]. Avoiding the use of an organic solvent, the encapsulation of bovine seroalbumin (BSA) using biodegradable copolymers has been carried out applying particles from gas-saturated solutions (PGSS) [130]. Zhong et al. developed a supercritical anti-solvent (SAS)-based process to manufacture, generally recognized as safe, (GRAS) delivery systems to release antimicrobials, thereby enhancing the shelf-lives of foods [131]. Corn zein was used as the carrier material and egg white lysozyme dissolved in $90 \%$ aqueous ethanol was microencapsulated. The authors revealed a long-time continuous release of antimicrobials of lysozyme at neutral pH conditions in the presence of salt. On the other hand, Kluge et al. studied the supercritical-fluid-extraction of emulsions (SFEE) process for the manufacturing of lysozyme-poly-lactic-co-glycolic acid (PLGA) composite particles for the delivery of lysozyme protein [132]. SFEE combines the efficiency of $\mathrm{SC}-\mathrm{CO}_{2}$ extraction with the facilities of water in oil $(w / o)$ or water in oil in water $(w / o / w)$ double emulsion methods. The $\mathrm{SC}-\mathrm{CO}_{2}$ and the emulsion feed streams are mixed at the inlet of the reactor in a two-coaxial nozzle. The particles are formed due to the organic solvent extraction from the emulsion droplets and remain suspended in the continuous water phase. Different encapsulation methods were tested and evaluated using ethyl acetate as organic solvent, but the encapsulation efficiencies were lower than $50 \%$. The authors concluded that despite the efficacy of SFEE process to produce solvent-free PLGA particles with small size and homogenous distribution, the encapsulation of drugs is more challenging for very hydrophilic compounds, such as peptides and proteins.

The use of different $\mathrm{SC}-\mathrm{CO}_{2}$ techniques for drying and atomization in protein-based processes was mainly limited to pharmaceutical applications, but research and development in the area of food-related products, including natural health ingredients, is increasing rapidly in recent years. Protein-based ingredients may be the single protein or multicomponent composite systems. The micronization of a single protein can improve bioavailability due to the increase of specific surface area, whereas composite systems refer to micro or nano particles where a certain active component is coated with the protein. In this respect, both proteins and polysaccharides are food-grade GRAS coatings and are preferred in food ingredient processing, in comparison with synthetic polymers (i.e., polyethylene glycol, polylactic acid, PLGA), which are especially selected as excipients for drug delivery in pharmaceuticals.

The supercritical drying of aqueous based solutions requires the use of very large quantities of $\mathrm{CO}_{2}$ due to the low solubility of water in SC-CO $\mathrm{CO}_{2}$ [145], or very high temperatures $\left(>120^{\circ} \mathrm{C}\right)$, as in the case of PGSS-drying [145] or PGX (gas-expanded liquids) [146].

Nuchuchua et al. have illustrated PGSS-drying as a scalable organic solvent free SC- $\mathrm{CO}_{2}$ spray drying process for producing dry protein/sugar formulations (1:10 and 1:4 $w / w$ ratios) [134]. Reibe et al. introduced the drying, micronization, and formulation of high molecular mass gelatine:aqueous gelatine solutions with a dry mass content of up to $50 \% w / w$, which were pulverised and dried with minor hydrolysis degradation during PGSS-drying supercritical processing [133].

In PGX, liquid ethanol expanded by the dissolution of $\mathrm{CO}_{2}$ is an appropriate choice for polysaccharides, or proteins drying. $\mathrm{SC}-\mathrm{CO}_{2}$ removes water but also can act as an antisolvent for the precipitation of the biopolymer. The process parameters must be 
selected to ensure a homogeneous single liquid phase of the ethanol-water- $\mathrm{CO}_{2}$ ternary system. Thus, the liquid-liquid mixing operation (aqueous biopolymer solution with $\mathrm{CO}_{2}$ expanded ethanol) avoids mass transfer problems involved in spraying processes. The precipitated polysaccharide, or protein, is collected on a filter after the liquid is drained by passing $\mathrm{SC}-\mathrm{CO}_{2}$. In this respect, expanded liquid anti-solvent (ELAS) protocol was used to denote the protein drying processes using $\mathrm{CO}_{2}$-expanded ethanol, acetone, and isopropyl alcohol. De Marco et al. used ELAS with $\mathrm{CO}_{2}$-expanded ethanol to yttrium acetate and BSA water-soluble materials, to produce micro and nanoparticles [136]. At the appropriate operating conditions, BSA spherical and non-coalescing particles were produced, with a narrow particle size distribution and mean diameter in the range $0.5-2.0 \mu \mathrm{m}$.

The supercritical assisted atomization (SAA) is another micronized technique that uses a thermostatic saturator to solubilize $\mathrm{CO}_{2}$ in the drug solution, and a thin wall injector to induce the atomization of the solution into the precipitator vessel. The fast release of $\mathrm{CO}_{2}$ from the primary formed droplets causes decompression and forms smaller secondary droplets. The SAA process was successfully applied to micronize antibiotics and polymers from either organic solvents or water, including protein micronization [137,147]. A hydrodynamic cavitation mixer (HCM) added to the saturator can intensify mass transfer between $\mathrm{CO}_{2}$ and the liquid solution. The SAA-HCM process was used [139] to produce lysozyme microparticles with a controlled particle size distribution. The particles were well defined (no agglomerates), spherical, and with $0.2-5.0 \mu \mathrm{m}$ diameters at the optimum operating conditions. Bioactivity assays showed the maintenance of $85 \%$ of lysozyme original activity. Furthermore, Wang et al. used this technique to prepare BSA microparticles from water solutions, obtaining different morphologies with particle diameters in the range of 0.3-5.0 $\mu \mathrm{m}$ [138]. Moreover, Shen et al. applied SAA-HCM to prepare micrometric particles of trypsin from aqueous solutions, obtaining several morphologies depending on the process conditions, while also analyzing the structural stability of the protein to conclude that trypsin retained above $70 \%$ of its biological activity [140]. Moreover, polymer chitosan was used to prepare trypsin composite microparticles, obtaining spherical microparticles with a homogeneous size distribution with $90 \%$ efficiency.

Supercritical solvent-assisted impregnation (SSI) is a more recent protein-based application of SC- $\mathrm{CO}_{2}$ technology. Trivedi et al. investigated the coating of protein-immobilised particles with myristic acid using SC- $\mathrm{CO}_{2}$ processing at low temperatures, in order to prevent thermal degradation of the protein (bovine haemoglobin, bHb) [141]. A solid core drug delivery system was prepared using $\mathrm{bHb}$ immobilisation on mesoporous silica followed by supercritical myristic acid coating at $43{ }^{\circ} \mathrm{C}$ and 100 bar. Protein particles were also coated via solvent evaporation to compare the protein release. In both methods, myristic acid coating provided good protection in gastric fluid media and limited the $\mathrm{bHb}$ release for the first two hours. After the change to intestinal fluid media, the protein release reached $70 \%$ within three hours. The release from supercritical samples was slower than with solvent evaporation formulations, indicating a superior myristic acid coverage, in addition to the protein conformation remaining unchanged after the release. Similarly, soy protein microparticles were coated with chia oil [142] using $\mathrm{SC}-\mathrm{CO}_{2}$. A good encapsulation efficiency was attained in the range of process conditions $100-160 \mathrm{bar}, 40-60^{\circ} \mathrm{C}$ and $0.0-0.1$ $w / w$ for the ethanol:oil ratio (ethanol was used as a co-solvent to increase the oil solubility in the $\mathrm{SC}-\mathrm{CO}_{2}$ ). The chia oil-loaded microparticles showed a spherical shape, no pores or fissures, sizes between 1 and $10 \mu \mathrm{m}$, and a homogeneous oil distribution. Furthermore, the hydroperoxide values and fatty acid profile indicated that the SSI process did not affect the chemical quality of the oil; the product showed an excellent oxidative stability, and almost all of the oil contained in the protein microparticles was released under gastro-intestinal conditions, remaining available for absorption.

It can be concluded that protein-based ingredients produced using $\mathrm{SC}-\mathrm{CO}_{2}$ technologies show good potential for further development, considering the growing demand for natural health products. Encapsulation of bioactive proteins is commonly accomplished using polysaccharides leading to dry powders which can be uniformly incorporated into 
different formulations even at low concentrations. In this way, efficient delivery systems can be designed. Varying supercritical processes parameters (temperature, pressure, flow rate ratios, nozzle diameter and depressurization rate, among others) the particle size, and morphology can be effectively controlled. Furthermore, low temperatures favour the handling of heat-sensitive substances, and circumventing the use of organic solvents, or the easy removal when they are used, is another key advantage of $\mathrm{SC}-\mathrm{CO}_{2}$ technology applied to the formation of bioactive protein-based microparticles.

\subsection{Structural and Conformational Modifications Resulting from $\mathrm{SC}-\mathrm{CO}_{2}$ Treatments}

Proteins and their products are used as ingredients in several food applications (dairy and bakery products, infant foods, and beverages) with the objective of enhancing nutritional value, creating emulsification, foaming, and antioxidant barriers, among others [148]. Since the functionality of food proteins are related to their structures, the structural modification of proteins can lead to new or improved functionalities [149]. In this respect, SC- $\mathrm{CO}_{2}$ treatment was described as a green method to achieve protein modification [150]. SC- $\mathrm{CO}_{2}$ offers many advantages in comparison with thermal processing methods, such as minimizing the alterations and quality of food [151]. Several studies have been reported, using $\mathrm{SC}-\mathrm{CO}_{2}$ for the inactivation of microorganisms and enzymes in liquid foods [152]. Despite many reports concerning the physical modification of polysaccharides under SC- $\mathrm{CO}_{2}$ processing [153], fewer studies can be found concerning the effects of $\mathrm{SC}-\mathrm{CO}_{2}$ treatment on protein quality and functionality.

For example, Zhong et al. analysed the effect of $\mathrm{SC}-\mathrm{CO}_{2}$ treatment on the rheological properties of whey protein [154]. The authors concluded that temperature, pressure, holding time, protein concentration, and $\mathrm{pH}$ were the main operating parameters influencing the conformational, structural, and functionalities of whey protein isolate (WPI). Later, $\mathrm{Xu}$ et al. conducted a complete analysis of the physical, conformational, and structural properties of WPI treated with SC- $\mathrm{CO}_{2}$ in comparison with the thermal treatment of WPI solution [150]. Increased turbidity of WPI treated with $\mathrm{SC}-\mathrm{CO}_{2}\left(50-60{ }^{\circ} \mathrm{C}\right.$ at $20 \mathrm{MPa}$ for $1 \mathrm{~h}$ ) suggested more intensive WPI denaturation in comparison with thermal processing. Furthermore, dynamic light scattering measurements showed higher aggregates and a maximum mean particle size when WPI was processed with $\mathrm{SC}-\mathrm{CO}_{2}$ at $60^{\circ} \mathrm{C}$, indicating the partial aggregation of the dimer into the polymers. An analysis of the fluorescence emission spectra of proteins suggested changes in the polarity of the protein residue's microenvironment from a less polar to a more polar. The authors evidenced secondary and tertiary protein structure changes induced by SC- $\mathrm{CO}_{2}$ treatment, resulting in physicochemical and functional properties of proteins.

The mechanisms of protein denaturalization due to $\mathrm{SC}-\mathrm{CO}_{2}$ treatment is actually a major topic of research due to its importance in cold sterilization methods. The complexity of the process has limited the possibility of attaining microstructural information related with microbial and/or enzyme inactivation by $\mathrm{SC}-\mathrm{CO}_{2}$. In a recent work, Monhemi and Dolatabadi used molecular dynamics simulation of $\mathrm{SC}-\mathrm{CO}_{2}$ pasteurization to conclude that the denaturation of proteins (myoglobin and lysozyme as models) is produced at the $\mathrm{CO}_{2}$ /water interface [155]. The protein migrates from a pure aqueous phase to the $\mathrm{CO}_{2}$ /water interface, releasing the hydrophobic cores to the $\mathrm{CO}_{2}$ phase and the hydrophilic residues to the aqueous phase and then the protein is denatured to a flat and extended conformation. Several other works have been recently reported, aiming to explain the molecular mechanisms of protein denaturalization in SC-CO $\mathrm{CO}_{2}$ [156,157], or describing novel food applications of $\mathrm{SC}-\mathrm{CO}_{2}$ enzyme inactivation. For example, Podrepšek et al. applied an $\mathrm{SC}-\mathrm{CO}_{2}$ treatment to inactivate the polyphenol oxidase enzyme in order to extend shelf life of a coarse-ground flour from whole wheat (graham flour) while preserving, at the same time, its high quality [158]. The effect of pressure on protein concentration and enzyme activity was significant, evidencing a 35\% decrease in polyphenol oxidase enzyme activity after SC-CO $\mathrm{CO}_{2}$ exposure at $300 \mathrm{bar}$ for $24 \mathrm{~h}$. Furthermore, the quality of the flour remained almost the same or even improved, indicating that the $\mathrm{SC}-\mathrm{CO}_{2}$-treated 
graham flour is still suitable for use in the bakery industry. Also, $\mathrm{SC}-\mathrm{CO}_{2}+$ ethanol extraction of yellow pea was found to enhance organoleptic attributes of the edible seed, reducing most chemical constituents, and lowering certain functionality qualities, such as pasting viscosities. Scanning electron micrographs indicated that protein-rich particles were adhered to the surface of starch granules of pea flour extracted with $\mathrm{SC}-\mathrm{CO}_{2}$, and this change may be responsible for the different functionality observed [157].

Thermal extrusion has been effectively used to improve the techno-functional properties of food proteins. The combination of temperature and shear weakens the structure of proteins and the extrusion process helps to partially unfold and denature proteins to modify their functionalities. SC- $\mathrm{CO}_{2}$ extrusion is an effective technique to produce conformational changes in proteins, providing several advantages in comparison to steam extrusion cooking, such as low-temperature processing, formation of a uniform and porous product, and $\mathrm{pH}$ control. For instance, the use of milk protein concentrate (MPC) in extruded products is still a challenge because of its sensitivity to high temperature and shear. For example, Yoon et al. have demonstrated the improved physicochemical properties of MPC extruded with $\mathrm{SC}-\mathrm{CO}_{2}$ in comparison with steam extrusion [158]. Also, Gopirajah et al. applied SC- $\mathrm{CO}_{2}$ extrusion to improve emulsifying properties of MPC, obtaining a better emulsion activity index, reduced creaming index, and similar viscosity as compared to commercial sodium caseinate [159].

Ding et al. showed that $\mathrm{SC}-\mathrm{CO}_{2}$ treatment can be a novel method to improve the foam ability of egg white protein [160]. At $9 \mathrm{MPa} \mathrm{SC}-\mathrm{CO}_{2}$ treatments, the protein foaming capacity increased 3.6 times in comparison with the original egg white. The protein electrostatic force was reduced due to the $\mathrm{pH}$ change and their particle size decreased. Accordingly, these effects resulted in an increase of protein hydrophobicity and viscosity.

\section{Conclusions}

Protein extraction is commonly considered to be a crucial step in contributing to the final greenness of the complete protein analysis process. In recent years, important advances have been achieved with the design, development, and application of novel methodological approaches for extracting high quality proteins at high yields. These new techniques also reduce the use of hazardous chemicals and solvents, and decrease the temperature and time conditions of the extraction process. Emerging eco-innovative extraction technologies are becoming a promising alternative to conventional methods for producing safe and nutritive proteins with preserved techno-functional properties. Furthermore, the combination of some of these methodologies with enzymatic hydrolysis has been demonstrated to improve the yield and biological properties of protein-derived peptides with the capability to be incorporated into functional foods and nutraceuticals. As presented in this review, although many advantages have been associated with the use of these technologies at a laboratory scale, the research is still in its infancy, thus further studies demonstrating their economical and environment suitability at an industrial scale are required.

Author Contributions: Conceptualization, T.F. and B.H.-L.; writing-original draft preparation, G.F.-O., T.F. and B.H.-L.; writing—review and editing, T.F. and B.H.-L. funding acquisition, B.H.-L. All authors have read and agreed to the published version of the manuscript.

Funding: This research was funded by the Spanish Ministry of Science and Innovation, projects PID2019-104218RB-I00/AEI/2015-66886R and PID2019-110183RB-C22/AEI/10.13039/501100011033.

Institutional Review Board Statement: Not applicable.

Informed Consent Statement: Not applicable.

Conflicts of Interest: The authors declare no conflict of interest. 


\section{References}

1. Chakrabarti, S.; Guha, S.; Majumder, K. Food-derived bioactive peptides in human health: Challenges and opportunities. Nutrients 2018, 10, 1738. [CrossRef] [PubMed]

2. Kumar, M.; Tomar, M.; Potkule, J.; Verma, R.; Punia, S.; Mahapatra, A.; Belwal, T.; Dahuja, A.; Joshi, S.; Berwal, M.K.; et al. Advances in the plant protein extraction: Mechanism and recommendations. Food Hydrocoll. 2021, 115, 106595. [CrossRef]

3. Lee, S.Y.; Show, P.L.; Ling, T.C.; Chang, J.S. Single-step disruption and protein recovery from Chlorella vulgaris using ultrasonication and ionic liquid buffer aqueous solutions as extractive solvents. Biochem. Eng. J. 2017, 124, 26-35. [CrossRef]

4. Chen, R.; Wang, X.J.; Zhang, Y.Y.; Xing, Y.; Yang, L.; Ni, H.; Li, H.-H. Simultaneous extraction and separation of oil, proteins, and glucosinolates from Moringa oleifera seeds. Food Chem. 2019, 300, 125162. [CrossRef] [PubMed]

5. Du, M.; Xie, J.; Gong, B.; Xu, X.; Tang, W.; Li, X.; Li, C.; Xie, M. Extraction physicochemical characteristics and functional properties of Mung bean protein. Food Hydrocoll. 2018, 76, 131-140. [CrossRef]

6. Feyzi, S.; Varidi, M.; Zare, F.; Varidi, M.J. Fenugreek (Trigonella foenum graecum) seed protein isolate: Extraction optimization, amino acid composition, thermo and functional properties. J. Sci. Food Agric. 2015, 95, 3165-3176. [CrossRef]

7. Bernardi, S.; Corso, M.; Baraldi, I.; Colla, E.; Canan, C. Obtaining concentrated rice bran protein by alkaline extraction and stirring-Optimization of conditions. Int. Food Res. J. 2018, 25, 1133-1139.

8. Hou, F.; Ding, W.; Qu, W.; Oladejo, A.O.; Xiong, F.; Zhang, W.; He, R.; Ma, H. Alkali solution extraction of rice residue protein isolates: Influence of alkali concentration on protein functional, structural properties and lysinoalanine formation. Food Chem. 2017, 218, 207-215. [CrossRef]

9. Shao, D.; Atungulu, G.G.; Pan, Z.; Yue, T.; Zhang, A.; Fan, Z. Characteristics of isolation and functionality of protein from tomato pomace produced with different industrial processing methods. Food Bioproc. Tech. 2014, 7, 532-541. [CrossRef]

10. Mechmeche, M.; Kachouri, F.; Chouabi, M.; Ksontini, H.; Setti, K.; Hamdi, M. Optimization of extraction parameters of protein isolate from tomato seed using response surface methodology. Food Anal. Methods 2017, 10, 809-819. [CrossRef]

11. Mori, K.; Goto-Yamamoto, N.; Kitayama, M.; Hashizume, K. Loss of anthocyanins in red-wine grape under high temperature. J. Exp. Bot. 2007, 58, 1935-1945. [CrossRef] [PubMed]

12. Pickardt, C.; Eisner, P.; Kammerer, D.R.; Carle, R. Pilot plant preparation of light-coloured protein isolates from de-oiled sunflower (Helianthus annuus L.) press cake by mild-acidic protein extraction and polyphenol adsorption. Food Hydrocol. 2015, 44, 208-219. [CrossRef]

13. Cui, Q.; Ni, X.; Zeng, L.; Tu, Z.; Li, J.; Sun, K.; Chen, X.; Li, X. Optimization of protein extraction and decoloration conditions for tea residues. Hortic. Plant J. 2017, 3, 172-176. [CrossRef]

14. Abelson, J.; Simon, M. Aqueous Two-Phase Systems; Methods in Enzymology; Academic Press: New York, NY, USA, 1994; Volume 228 .

15. Varadavenkatesan, T.; Pai, S.; Vinayagam, R.; Pugazhendhi, A.; Selvaraj, R. Recovery of value-added products from waste water using Aqueous Two-Phase Systems-A review. Sci. Total Env. 2021, 778, 146293. [CrossRef] [PubMed]

16. Saravana Pandian, P.; Sindhanai Selvan, S.; Subathira, A.; Saravanan, S. Optimization of aqueous two phase extraction of proteins from Litopenaeus vannamei waste by response surface methodology coupled multi-objective genetic algorithm. Chem. Prod. Process. Model. 2019, 15, 20190034. [CrossRef]

17. Menegotto, A.L.L.; Fernandes, I.A.; Bucior, D.; Balestieri, B.P.; Colla, L.M.; Abirached, C.; Franceschi, E.; Steffens, J.; Valduga, E. Purification of protein from Arthrospira platensis using aqueous two-phase system associate with membrane separation process and evaluation of functional properties. J. Appl. Phycol. 2021. [CrossRef]

18. Zhang, J.; Wen, C.; Zhang, H.; Duan, Y.; Ma, H. Recent advances in the extraction of bioactive compounds with subcriticalwater: A review. Trends Food Sci. Technol. 2020, 95, 183-195. [CrossRef]

19. Mlyuka, E.; Mbifile, M.; Zhang, S.; Zheng, Z.; Chen, J. Strategic applications and the challenges of subcritical water extraction technology in food industries. Chiang Mai J. Sci. 2018, 45, 1015-1029. Available online: https://www.thaiscience.info/Journals/ Article/CMJS/10989357.pdf (accessed on 6 September 2021).

20. Marcet, I.; Álvarez, C.; Paredes, B.; Díaz, M. The use of subcritical water hydrolysis for the recovery of peptides and free amino acids from food processing wastes. Review of sources and main parameters. Waste Manag. 2016, 49, 364-371. [CrossRef] [PubMed]

21. Lamp, A.; Kaltschmitt, M.; Lüdtke, O. Protein recovery from bioethanol stillage by liquid hot water treatment. J. Supercrit. Fluids 2020, 155, 104624. [CrossRef]

22. Álvarez-Viñas, M.; Rodríguez-Seoane, P.; Flórez-Fernández, N.; Torres, M.D.; Díaz-Reinoso, B.; Moure, A.; Domínguez, H. Subcritical water for the extraction and hydrolysis of protein and other fractions in biorefineries from agro-food wastes and algae: A review. Food Bioproc. Tech. 2021, 14, 373-387. [CrossRef]

23. Pojić, M.; Mišan, A.; Tiwari, B. Eco-innovative technologies for extraction of proteins for human consumption from renewable protein sources of plant origin. Trends Food Sci. Technol. 2018, 75, 93-104. [CrossRef]

24. Sari, Y.W.; Bruins, M.E.; Sanders, J.P.M. Enzyme assisted protein extraction from rapeseed, soybean, and microalgae meals. Ind. Crops Prod. 2013, 43, 78-83. [CrossRef]

25. Liu, J.-J.; Gasmalla, M.A.A.; Li, P.; Yang, R. Enzyme-assisted extraction processing from oilseeds: Principle, processing and application. Innov. Food Sci. Emerg. Technol. 2016, 35, 184-193. [CrossRef] 
26. Ochoa-Rivas, A.; Nava-Valdez, Y.; Serna-Saldívar, S.O.; Chuck-Hernández, C. Microwave and ultrasound to enhance protein extraction from peanut flour under alkaline conditions: Effects in yield and functional properties of protein isolates. Food Bioproc. Technol. 2017, 10, 543-555. [CrossRef]

27. Rommi, K.; Hakala, T.K.; Holopainen, U.; Nordlund, E.; Poutanen, K.; Lantto, R. Effect of enzyme-aided cell wall disintegration on protein extractability from intact and dehulled rapeseed (Brassica rapa L. and Brassica napus L.) press cakes. J. Agric. Food Chem. 2014, 62, 7989-7997. [CrossRef] [PubMed]

28. Rommi, K.; Ercili-Cura, D.; Hakala, T.K.; Nordlund, E.; Poutanen, K.; Lantto, R. Impact of total solid content and extraction pH on enzyme-aided recovery of protein from defatted rapeseed (Brassica rapa L.) press cake and physicochemical properties of the protein fractions. J. Agric. Food Chem. 2015, 63, 2997-3003. [CrossRef] [PubMed]

29. Chirinos, R.; Aquino, M.; Pedreschi, R.; Campos, D. Optimized methodology for alkaline and enzyme assisted extraction of protein from Sacha Inchi (Plukenetia volubilis) kernel cake. J. Food Proc. Eng. 2016, 40, e12412. [CrossRef]

30. Houde, M.; Khodaei, N.; Benkerroum, N.; Karboune, S. Barley protein concentrates: Extraction, structural and functional properties. Food Chem. 2018, 254, 367-376. [CrossRef]

31. Perovic, M.N.; Zorica, D.K.J.; Mirjana, G.A. Improved recovery of protein from soy grit by enzyme-assisted alkaline extraction. J. Food Eng. 2020, 276, 109894. [CrossRef]

32. Naseri, A.; Marinho, G.S.; Holdt, S.L.; Bartela, J.M.; Jacobsen, C. Enzyme-assisted extraction and characterization of protein from red seaweed Palmaria palmata. Algal Res. 2020, 47, 101849. [CrossRef]

33. Akyüz, A.; Ersus, S. Optimization of enzyme assisted extraction of protein from the sugar beet (Beta vulgaris L.) leaves for alternative plant protein concentrate production. Food Chem. 2021, 335, 127673. [CrossRef]

34. De Souza, T.S.P.; Dias, F.F.G.; Oliveira, J.P.S.; de Moura Bell, J.M.N.L.; Koblitz, M.G.B. Biological properties of almond proteins produced by aqueous and enzyme-assisted aqueous extraction processes from almond cake. Sci. Rep. 2020, 10, 10873. [CrossRef]

35. Gil-Chávez, G.J.; Villa, J.A.; Ayala-Zavala, J.F.; Basilio Heredia, J.; Sepulveda, D.; Yahia, E.M.; González-Aguilar, G.A. Technologies for extraction and production of bioactive compounds to be used as nutraceuticals and food ingredients: An overview. Compr. Rev. Food Sci. Food Saf. 2013, 12, 5-23. [CrossRef]

36. Camel, V. Microwave-assisted solvent extraction of environmental samples. Trends Anal. Chem. 2000, 19, 229-248. [CrossRef]

37. Chan, C.H.; Yusoff, R.; Ngoh, G.C.; Kung, F.W.L. Microwave-assisted extractions of active ingredients from plants. J. Chromatogr. A 2011, 1218, 6213-6225. [CrossRef] [PubMed]

38. Chan, C.H.; Yusoff, R.; Ngoh, G.C. Assessment of scale-up parameters of microwave-assisted extraction via the extraction of flavonoids from cocoa leaves. Chem. Eng. Technol. 2015, 38, 489-496. [CrossRef]

39. Chemat, F.; Huma, Z.; Khan, M.K. Applications of ultrasound in food technology: Processing, preservation and extraction. Ultrason. Sonochem. 2011, 18, 813-835. [CrossRef]

40. Phongthai, S.; Lim, S.-T.; Rawdkuen, S. Optimization of microwave-assisted extraction of rice bran protein and its hydrolysates properties. J. Cereal Sci. 2016, 70, 154-156. [CrossRef]

41. Bedin, S.; Zanella, K.; Bragagnolo, N.; Taranto, O.P. Implications of microwaves on the extraction process of rice bran protein. Braz. J. Chem. Eng. 2019, 36, 1653-1665. [CrossRef]

42. Park, J.-H.; Choe, J.-H.; Kim, H.-W.; Hwang, K.-E.; Song, D.-H.; Yeo, E.-J.; Kim, H.-Y.; Choi, Y.-S.; Lee, S.-H.; Kim, C.-J. Effects of various extraction methods on quality characteristics of duck feet gelatin. Korean J. Food Sci. An. 2013, 33, 162-169. [CrossRef]

43. Zhu, K.-X.; Sun, X.-H.; Zhou, H.-M. Optimization of ultrasound assisted extraction of defatted wheat germ proteins by reverse micelles. J. Cereal Sci. 2009, 50, 266-271. [CrossRef]

44. Görgüç, A.; Bircan, C.; Yılmaz, F.M. Sesame bran as an unexploited by-product: Effect of enzyme and ultrasound assisted extraction on the recovery of protein and antioxidant compounds. Food Chem. 2019, 283, 637-645. [CrossRef]

45. Görgüç, A.; Özer, P.; Yılmaz, F.M. Microwave-assisted enzymatic extraction of plant protein with antioxidant compounds from the food waste sesame bran: Comparative optimization study and identification of metabolomics using LC/Q-OF/MS. J. Food Process. Preserv. 2019, 44, e14304. [CrossRef]

46. Leong, T.; Ashokkumar, M.; Kentish, S. The fundamentals of power ultrasound-A review. Acoust. Aust. 2011, $39,54-63$.

47. Rahman, M.M.; Lamsal, B.P. Ultrasound-assisted extraction and modification of plant-based proteins: Impact on physicochemical, functional, and nutritional properties. Compr. Rev. Food Sci. Food Saf. 2020, 20, 1457-1480. [CrossRef]

48. Bhargavaa, N.; Mor, R.S.; Kumar, K.; Sharanagat, V.J. Advances in application of ultrasound in food processing: A review. Ultrason. Sonochem. 2020, 70, 105293. [CrossRef]

49. Sun, X.; Zhang, W.; Zhang, L.; Tian, S.; Chen, F. Molecular and emulsifying properties of arachin and conarachin of peanut protein isolate from ultrasound-assisted extraction. LWT-Food Sci. Technol. 2020, 132, 109790. [CrossRef]

50. Wang, F.; Zhang, Y.; Xu, L.; Ma, H. An efficient ultrasound-assisted extraction method of pea protein and its effect on protein functional properties and biological activities. LWT-Food Sci. Technol. 2020, 127, 109348. [CrossRef]

51. Hadidi, M.; Baradaran Khaksar, F.; Pagan, J.; Ibarz, A. Application of ultrasound-ultrafiltration-assisted alkaline isoelectric precipitation (UUAAIP) technique for producing alfalfa protein isolate for human consumption: Optimization, comparison, physicochemical, and functional properties. Food Res. Int. 2020, 130, 108907. [CrossRef] [PubMed]

52. Zou, Y.; Li, P.P.; Zhang, K.; Wang, L.; Zhang, M.H.; Sun, Z.L.; Sun, C.; Geng, Z.M.; Xu, W.M.; Wang, D.Y. Effects of ultrasoundassisted alkaline extraction on the physiochemical and functional characteristics of chicken liver protein isolate. Poult. Sci. 2017, 96, 2975-2985. [CrossRef] 
53. Mirzapour-Kouhdasht, A.; Sabzipour, F.; Taghizadeh, M.S.; Moosavi-Nasab, M. Physicochemical, rheological, and molecular characterization of colloidal gelatin produced from Common carp by-products using microwave and ultrasound-assisted extraction. J. Texture Stud. 2019, 50, 416-425. [CrossRef]

54. Pingret, D.; Fabiano-Tixier, A.S.; Chemat, F. Degradation during application of ultrasound in food processing: A review. Food Cont. 2013, 31, 593-606. [CrossRef]

55. Yang, X.; Li, Y.; Li, S.; Oladejo, A.O.; Wang, Y.; Huang, S.; Zhou, C.; Ye, X.; Ma, H.; Duan, Y. Effects of ultrasound-assisted $\alpha$-amylase degradation treatment with multiple modes on the extraction of rice protein. Ultrason. Sonochem. 2018, 40, 890-899. [CrossRef] [PubMed]

56. Görgüç, A.; Özer, P.; Yılmaz, F.M. Simultaneous effect of vacuum and ultrasound assisted enzymatic extraction on the recovery of plant protein and bioactive compounds from sesame bran. J. Food Comp. Anal. 2020, 87, 103424. [CrossRef]

57. Li, W.; Yang, H.; Coldea, T.E.; Zhao, H. Modification of structural and functional characteristics of brewer's spent grain protein by ultrasound assisted extraction. LWT-Food Sci. Technol. 2021, 139, 110582. [CrossRef]

58. Varghese, T.; Pare, A. Effect of microwave assisted extraction on yield and protein characteristics of soymilk. J. Food Eng. 2019, 262, 92-99. [CrossRef]

59. Moreno-Nájera, L.C.; Ragazzo-Sánchez, J.A.; Gastón-Peña, C.R.; Calderón-Santoyo, M. Green technologies for the extraction of proteins from jackfruit leaves (Artocarpus heterophyllus Lam). Food Sci. Biotechnol. 2020, 29, 1675-1684. [CrossRef]

60. Elhag, H.E.E.A.; Naila, A.; Nour, A.H.; Ajit, A.; Sulaiman, A.Z.; Aziz, B.A. Optimization of protein yields by ultrasound assisted extraction from Eurycoma longifolia roots and effect of agitation speed. J. King Saud Univ. Sci. 2019, 31, 913-930. [CrossRef]

61. Wen, L.; Álvarez, C.; Zhang, Z.; Poojary, M.M.; Lund, M.N.; Sun, D.-W.; Tiwari, B.K. Optimisation and characterisation of protein extraction from coffee silverskin assisted by ultrasound or microwave techniques. Biomass Convers. Biorefin. 2020. [CrossRef]

62. Zhao, Y.; Wen, C.; Feng, Y.; Zhang, J.; He, Y.; Duan, Y.; Zhang, H.; Ma, H. Effects of ultrasound-assisted extraction on the structural, functional and antioxidant properties of Dolichos lablab L. protein. Proc. Biochem. 2021, 101, 274-284. [CrossRef]

63. Tu, Z.-C.; Huang, T.; Wang, H.; Sha, X.-M.; Shi, Y.; Huang, X.-Q.; Man, Z.-Z.; Li, D.-J. Physico-chemical properties of gelatin from bighead carp (Hypophthalmichthys nobilis) scales by ultrasound-assisted extraction. J. Food Sci. Technol. 2015, 52, $2166-2174$. [CrossRef]

64. Chemat, F.; Vian, M.A.; Fabiano-Tixier, A.S.; Nutrizio, M.; Jambrak, A.R.; Munekata, P.E.S.; Lorenzo, J.M.; Barba, F.J.; Binelloe, A.; Cravotto, G. A review of sustainable and intensified techniques for extraction of food and natural products. Green Chem. 2020, 22, 2325-2353. [CrossRef]

65. Ganeva, V.; Angelova, B.; Galutzov, B.; Goltsev, V.; Zhiponova, M. Extraction of proteins and other intracellular bioactive compounds from baker's yeasts by pulsed electric field treatment. Front. Bioeng. Biotechnol. 2020, 8, 552335. [CrossRef]

66. Arshad, R.N.; Abdul-Malek, Z.; Roobab, U.; Qureshi, M.I.; Khan, N.; Ahmad, M.H.; Liu, Z.-W.; Aadil, R.M. Effective valorization of food wastes and by-products through pulsed electric field: A systematic review. J. Food Process. Eng. 2021, 44 , e13629. [CrossRef]

67. Martínez, J.M.; Delso, C.; Maza, M.A.; Raso, J. Utilising pulsed electric field processing to enhance extraction processes. In Reference Module in Food Science; Elsevier: New York, NY, USA, 2018. [CrossRef]

68. Roselló-Soto, E.; Barba, F.J.; Parniakov, O.; Galanakis, C.M.; Lebovka, N.; Grimi, N.; Vorobiev, E. High voltage electrical discharges, pulsed electric field, and ultrasound assisted extraction of protein and phenolic compounds from olive kernel. Food Bioprocess. Technol. 2014. [CrossRef]

69. Sarkis, J.R.; Boussetta, N.; Blouet, C.; Tessaro, I.C.; Marczak, L.D.F.; Vorobiev, E. Effect of pulsed electric fields and high voltage electrical discharges on polyphenol and protein extraction from sesame cake. Innov. Food Sci. Emerg. Technol. 2015, 29, 170-177. [CrossRef]

70. 't Lama, G.P.; Postma, P.R.; Fernandes, D.A.; Timmermans, R.A.H.; Vermuë, M.H.; Barbosa, M.J.; Eppink, M.H.M.; Wijffels, R.H.; Olivieri, G. Pulsed electric field for protein release of the microalgae Chlorella vulgaris and Neochloris oleoabundans. Algal Res. 2017, 24, 181-187. [CrossRef]

71. Zhang, L.; Wang, L.-J.; Jiang, W.; Qian, J.-Y. Effect of pulsed electric field on functional and structural properties of canola protein by pretreating seeds to elevate oil yield. Lebensm.-Wiss. Technol. 2017, 84, 73-81. [CrossRef]

72. Liang, R.; Cheng, S.; Wang, X. Secondary structure changes induced by pulsed electric field affect antioxidant activity of pentapeptides from pine nut (Pinus koraiensis) protein. Food Chem. 2018, 254, 170-184. [CrossRef] [PubMed]

73. Shouqin, Z.; Jun, X.; Changzheng, W. High hydrostatic pressure extraction of flavonoids from propolis. J. Chem. Technol. Biotechnol. Int. Res. Process Envir. Clean Technol. 2005, 80, 50-54. [CrossRef]

74. Sezer, P.; Okur, I.; Oztop, M.H.; Alpas, H. Improving the physical properties of fish gelatin by high hydrostatic pressure (HHP) and ultrasonication (US). Int. J. Food Sci. Technol. 2019, 55, 1468-1476. [CrossRef]

75. Suwal, S.; Perreault, V.; Marciniak, A.; Tamigneaux, E.; Deslandes, E.; Bazinet, L.; Jacques, H.; Beaulieu, L.; Doyen, A. Effects of high hydrostatic pressure and polysaccharidases on the extraction of antioxidant compounds from red macroalgae, Palmaria palmata Solieria chordalis. J. Food Eng. 2019, 52, 53-59. [CrossRef]

76. Cascaes Teles, A.S.; Hidalgo Chávez, D.W.; Zarur Coelho, M.A.; Rosenthal, A.; Fortes Gottschalk, L.M.; Tonon, R.V. Combination of enzyme-assisted extraction and high hydrostatic pressure for phenolic compounds recovery from grape pomace. J. Food Eng. 2020, 288, 110128. [CrossRef] 
77. Bolat, B.; Ugur, A.E.; Oztop, M.H.; Alpas, H. Effects of high hydrostatic pressure assisted degreasing on the technological properties of insect powders obtained from Acheta domesticus \& Tenebrio molitor. J. Food Eng. 2021, 292, 110359. [CrossRef]

78. Gharibzahedi, S.M.T.; Smith, B. Effects of high hydrostatic pressure on the quality and functionality of protein isolates, concentrates, and hydrolysates derived from pulse legumes: A review. Trends Food Sci. Technol. 2021, 107, 466-479. [CrossRef]

79. Marciniak, A.; Suwal, S.; Naderi, N.; Pouliot, Y.; Doyen, A. Enhancing enzymatic hydrolysis of food proteins and production of bioactive peptides using high hydrostatic pressure technology. Trends Food Sci. Technol. 2018, 80, 187-198. [CrossRef]

80. Rivalain, N.; Roquain, J.; Demazeau, G. Development of high hydrostatic pressure in biosciences: Pressure effect on biological structures and potential applications in Biotechnologies. Biotechnol. Adv. 2010, 28, 659-672. [CrossRef]

81. Ahmed, J.; Mulla, M.; Al-Ruwaih, N.; Arfat, Y.A. Effect of high-pressure treatment prior to enzymatic hydrolysis on rheological, thermal, and antioxidant properties of lentil protein isolate. Legume Sci. 2019, 1, e10. [CrossRef]

82. Tribst, A.A.L.; Ribeiro, L.R.; Cristianini, M. Comparison of the effects of high pressure homogenization and high pressure processing on the enzyme activity and antimicrobial profile of lysozyme. Innov. Food Sci. Emerg. Technol. 2017, 43, 60-67. [CrossRef]

83. Ulug, S.K.; Jahandideh, F.; Wu, J. Novel technologies for the production of bioactive peptides. Trends Food Sci. Technol. 2021, 108, 27-39. [CrossRef]

84. Espinoza, A.D.; Morawicki, R.O.; Hager, T. Hydrolysis of whey protein isolate using subcritical water. J. Food Sci. 2012, 71, C20-C26. [CrossRef] [PubMed]

85. Hall, F.; Liceaga, A. Effect of microwave-assisted enzymatic hydrolysis of cricket (Gryllodes sigillatus) protein on ACE and DPP-IV inhibition and tropomyosin-IgG binding. J. Funct. Foods 2020, 64, 103634. [CrossRef]

86. Urbizo-Reyes, U.; San Martin-González, M.F.; Garcia-Bravo, J.; López Malo Vigil, A.; Liceaga, A.M. Physicochemical characteristics of chia seed (Salvia hispanica) protein hydrolysates produced using ultrasonication followed by microwave-assisted hydrolysis. Food Hydrocoll. 2019, 97, 105187. [CrossRef]

87. Chen, Z.; Li, Y.; Lin, S.; Wei, M.; Du, F.; Ruan, G. Development of continuous microwave-assisted protein digestion with immobilized enzyme. Biochem. Biophys. Res. Commun. 2014, 445, 491-496. [CrossRef] [PubMed]

88. Uluko, H.; Zhang, S.; Liu, L.; Tsakama, M.; Lu, J.; Lv, J. Effects of thermal, microwave, and ultrasound pretreatments on antioxidative capacity of enzymatic milk protein concentrate hydrolysates. J. Funct. Foods 2015, 18, 1138-1146. [CrossRef]

89. Yang, F.; Hu, F.; Jiang, Q.; Xu, Y.; Xia, W. Effect of pretreatments on hydrolysis efficiency and antioxidative activity of hydrolysates produced from bighead carp (Aristichthys nobilis). J. Aquat. Food Prod. Technol. 2016, 25, 916-927. [CrossRef]

90. Nguyen, E.; Jones, O.; Kim, Y.H.B.; San Martin-Gonzalez, F.; Liceaga, A.M. Impact of microwave-assisted enzymatic hydrolysis on functional and antioxidant properties of rainbow trout Oncorhynchus mykiss by-products. Fish. Sci. 2017, 83, 317-331. [CrossRef]

91. Ketnawa, S.; Wickramathilaka, M.; Liceaga, A.M. Changes on antioxidant activity of microwave-treated protein hydrolysates after simulated gastrointestinal digestion: Purification and identification. Food Chem. 2018, 254, 36-46. [CrossRef]

92. Li, Y.; Li, J.; Lin, S.J.; Yang, Z.S.; Jin, H.X. Preparation of antioxidant peptide by microwave- assisted hydrolysis of collagen and its protective effect against $\mathrm{H}_{2} \mathrm{O}_{2}$-induced damage of RAW264.7 cells. Mar. Drugs 2019, 17, 642. [CrossRef]

93. Sparr Eskilsson, C.; Björklund, E. Analytical-scale microwave-assisted extraction. J. Chromatogr. A 2000, 902, 227-250. [CrossRef]

94. Jia, J.; Ma, H.; Zhao, W.; Wang, Z.; Tian, W.; Luo, L.; He, R. The use of ultrasound for enzymatic preparation of ACE-inhibitory peptides from wheat germ protein. Food Chem. 2010, 119, 336-342. [CrossRef]

95. Zhu, K.-X.; Su, C.-Y.; Guo, X.-N.; Peng, W.; Zhou, H.-M. Influence of ultrasound during wheat gluten hydrolysis on the antioxidant activities of the resulting hydrolysate. Int. J. Food Sci. Technol. 2011, 46, 1053-1059. [CrossRef]

96. Wali, A.; Ma, H.; Shahnawaz, M.; Hayat, K.; Xiaong, J.; Jing, L. Impact of power ultrasound on antihypertensive activity, functional properties, and thermal stability of rapeseed protein hydrolysates. J. Chem. 2017, 2017, 4373859. [CrossRef]

97. Wu, Q.; Zhang, X.; Jia, J.; Kuang, C.; Yang, H. Effect of ultrasonic pretreatment on whey protein hydrolysis by alcalase: Thermodynamic parameters, physicochemical properties and bioactivities. Proc. Biochem. 2018, 67, 46-54. [CrossRef]

98. Lei, B.; Majumder, K.; Shen, S.; Wu, J. Effect of sonication on thermolysin hydrolysis of ovotransferrin. Food Chem. 2011, 124, 808-815. [CrossRef]

99. Piccolomini, A.; Iskandar, M.; Lands, L.; Kubow, S. High hydrostatic pressure pre-treatment of whey proteins enhances whey protein hydrolysate inhibition of oxidative stress and IL-8 secretion in intestinal epithelial cells. Food Nutr. Res. 2012, 56, 17549. [CrossRef]

100. Boukil, A.; Suwal, S.; Chamberland, J.; Pouliot, Y.; Doyen, A. Ultrafiltration performance and recovery of bioactive peptides after fractionation of tryptic hydrolysate generated from pressure-treated B-lactoglobulin. J. Membr. Sci. 2018, 556, 42-53. [CrossRef]

101. Garcia-Mora, P.; Peñas, E.; Frias, J.; Zielinski, H.; Wiczkowski, W.; Zielinska, D.; Martínez-Villaluenga, C. High-pressure-assisted enzymatic release of peptides and phenolics increases angiotensin converting enzyme I inhibitory and antioxidant activities of pinto bean hydrolysates. J. Agric. Food Chem. 2016, 64, 1730-1740. [CrossRef]

102. Al-Ruwaih, N.; Ahmed, J.; Mulla, M.F.; Arfat, Y.A. High-pressure assisted enzymatic proteolysis of kidney beans protein isolates and characterization of hydrolysates by functional, structural, rheological and antioxidant properties. LWT- Food Sci. Technol. 2019, 100, 231-236. [CrossRef]

103. Guan, H.; Diao, X.; Jiang, F.; Han, J.; Kong, B. The enzymatic hydrolysis of soy protein isolate by corolase PP under high hydrostatic pressure and its effect on bioactivity and characteristics of hydrolysates. Food Chem. 2018, 245, 89-96. [CrossRef] 
104. Perreault, V.; Hénaux, L.; Bazinet, L.; Doyen, A. Pretreatment of flaxseed protein isolate by high hydrostatic pressure: Impacts on protein structure, enzymatic hydrolysis and final hydrolysate antioxidant capacities. Food Chem. 2017, 221, 1805-1812. [CrossRef]

105. Franco, D.; Munekata, P.E.S.; Agregán, R.; Bermúdez, R.; López-Pedrouso, M.; Pateiro, M.; Lorenzo, J.M. Application of pulsed electric fields for obtaining antioxidant extracts from fish residues. Antioxidants 2020, 9, 90. [CrossRef] [PubMed]

106. Lin, S.; Guo, Y.; Liu, J.; You, Q.; Yin, Y.; Cheng, S. Optimized enzymatic hydrolysis and pulsed electric field treatment for production of antioxidant peptides from egg white protein. Afr. J. Biotechnol. 2011, 10, 11648-11657.

107. Lin, S.; Guo, Y.; You, Q.; Yin, Y.; Liu, J. Preparation of antioxidant peptide from egg white protein and improvement of its activities assisted by high-intensity pulsed electric field. J. Sci. Food Agric. 2012, 92, 1554-1561. [CrossRef] [PubMed]

108. Lin, S.; Jin, Y.; Liu, M.; Yang, Y.; Zhang, M.; Guo, Y.; Jones, G.; Liu, J.; Yin, Y. Research on the preparation of antioxidant peptides derived from egg white with assisting of high intensity pulsed electric field. Food Chem. 2013, 139, 300-306. [CrossRef]

109. Lin, S.; Liang, R.; Li, X.; Xing, J.; Yuan, Y. Effect of pulsed electric field (PEF) on structures and antioxidant activity of soybean source peptides-SHCMN. Food Chem. 2016, 213, 588-594. [CrossRef] [PubMed]

110. Kumar, Y.; Patel, K.K.; Kumar, V. Pulsed electric field processing in food technology. Int. J. Eng. Stud. Techn. Approach 2015, 1, 6-16. [CrossRef]

111. Asaduzzaman, A.K.M.; Getachewa, A.T.; Cho, Y.-J.; Park, J.S.; Haq, M.; Chun, B.-S. Characterization of pepsin-solubilised collagen recovered from mackerel (Scomber japonicus) bone and skin using subcritical water hydrolysis. Int. J. Biol. Macromol. 2020, 148, 1290-1297. [CrossRef]

112. Wang, M.P.; Lu, W.; Yang, J.; Wang, J.M.; Yang, X.Q. Preparation and characterisation of isoflavone aglycone-rich calcium-binding soy protein hydrolysates. Int. J. Food Sci. Technol. 2017, 52, 2230-2237. [CrossRef]

113. Han, J.; Kim, M.R.; Park, Y.; Hong, Y.H.; Suh, H.J. Skin permeability of porcine placenta extracts and its physiological activities. Korean J. Food Sci. Anim. Res. 2013, 33, 356-362. [CrossRef]

114. Espinosa-Pardo, F.A.; Savoire, R.; Subra-Paternault, P.; Harscoat-Schiavo, C. Oil and protein recovery from corn germ: Extraction yield, composition and protein functionality. Food Bioprod. Process. 2020, 120, 131-142. [CrossRef]

115. Li, Y.; Shi, J.; Scanlon, M.; Xue, S.J.; Lu, J. Effects of pretreatments on physicochemical and structural properties of proteins isolated from canola seeds after oil extraction by supercritical- $\mathrm{CO}_{2}$ process. LWT Food Sci. Technol. 2020, 137, 110415. [CrossRef]

116. Olivera-Montenegro, L.; Best, I.; Gil-Saldarriaga, A. Effect of pretreatment by supercritical fluids on antioxidant activity of protein hydrolyzate from quinoa (Chenopodium quinoa Willd.). Food Sci. Nutr. 2021, 9, 574-582. [CrossRef]

117. Koh, B.-B.; Lee, E.-J.; Ramachandraiah, K.; Hong, G.-P. Characterization of bovine serum albumin hydrolysates prepared by subcritical water processing. Food Chem. 2019, 278, 203-207. [CrossRef]

118. Powell, T.; Bowra, S.; Cooper, H.J. Subcritical water processing of proteins: An alternative to enzymatic digestion. Anal. Chem. 2016, 88, 6425-6432. [CrossRef]

119. Choi, J.-S.; Moon, H.E.; Roh, M.K.; Ha, V.M.; Lee, B.B.; Cho, K.K.; Choi, I.S. Physiological properties of Scomber japonicus meat hydrolysate prepared by subcritical water hydrolysis. J. Env. Biol. 2016, 37, 57-63.

120. Haq, M.; Ho, T.C.; Ahmed, R.; Getachew, A.T.; Cho, Y.-J.; Park, J.-S.; Chun, B.-S. Biofunctional properties of bacterial collagenolytic protease-extracted collagen hydrolysates obtained using catalysts-assisted subcritical water hydrolysis. J. Ind. Eng. Chem. 2020, 81, 332-339. [CrossRef]

121. Ahmed, R.; Chun, B.S. Subcritical water hydrolysis for the production of bioactive peptides from tuna skin collagen. J. Supercrit. Fluids 2018, 141, 88-96. [CrossRef]

122. Melgosa, R.; Marques, M.; Paiva, A.; Bernardo, A.; Fernández, N.; Sá-Nogueira, I.; Simões, P. Subcritical water extraction and hydrolysis of cod (Gadus morhua) frames to produce bioactive protein extracts. Foods 2021, 10, 1222. [CrossRef]

123. Lee, H.-J.; Roy, V.C.; Ho, T.C.; Park, J.-S.; Jeong, Y.-R.; Lee, S.C.; Kim, S.-Y.; Chun, B.-S. Amino acid profiles and biopotentiality of hydrolysates obtained from comb penshell (Atrina pectinata) viscera using subcritical water hydrolysis. Mar. Drugs 2021, 19, 137. [CrossRef] [PubMed]

124. Polikovsky, M.; Gillis, A.; Steinbruch, E.; Robin, A.; Epstein, M.; Kribus, A.; Golberg, A. Biorefinery for the co-production of protein, hydrochar and additional co-products from a green seaweed Ulva sp. with subcritical water hydrolysis. Energy Convers. Manag. 2020, 225, 113380. [CrossRef]

125. Park, J.-S.; Jeong, Y.-R.; Chun, B.S. Physiological activities and bioactive compound from laver (Pyropia yezoensis) hydrolysates by using subcritical water hydrolysis. J. Supercrit. Fluids 2019, 148, 130-136. [CrossRef]

126. Ramachandraiah, K.; Koh, B.-B.; Davaatseren, M.; Hong, G.-P. Characterization of soy protein hydrolysates produced by varying subcritical water processing temperature. Innov. Food Sci. Emerg. Technol. 2017, 43, 201-206. [CrossRef]

127. Fusaro, F.; Kluge, J.; Mazzotti, M.; Muhrer, G. Compressed $\mathrm{CO}_{2}$ antisolvent precipitation of lysozyme. J. Supercrit. Fluids 2009, 49, 79-92. [CrossRef]

128. Moshashaée, S.; Bisrat, M.; Forbes, R.T.; Nyqvist, H.; York, P. Supercritical fluid processing of proteins I: Lysozyme precipitation from organic solution. Eur. J. Pharm. Sci. 2000, 11, 239-245. [CrossRef]

129. Yver, A.L.; Bonnaillie, L.M.; Yee, W.; McAloon, A.; Tomasula, P.M. Fractionation of whey protein isolate with supercritical carbon dioxide - Process modeling and cost estimation. Int. J. Mol. Sci. 2012, 13, 240-259. [CrossRef]

130. Perinelli, D.R.; Bonacucina, G.; Cespi, M.; Naylor, A.; Whitaker, M.; Palmieri, G.F.; Giorgioni, G.; Casettari, L. Evaluation of P(L)LA-PEG-P(L)LA as processing aid for biodegradable particles from gas saturated solutions (PGSS) process. Int. J. Pharm. 2014, 468, 250-257. [CrossRef] 
131. Zhong, Q.; Jin, M.; Xiao, D.; Tian, H.; Zhang, W. Application of supercritical antisolvent technologies for the synthesis of delivery systems of bioactive food components. Food Biophys. 2008, 3, 186-190. [CrossRef]

132. Kluge, J.; Fusaro, F.; Casas, N.; Mazzotti, M.; Muhrer, G. Production of PLGA micro and nanocomposites by supercritical fluid extraction of emulsions: I. encapsulation of lysozyme. J. Supercrit. Fluids 2009, 50, 327-335. [CrossRef]

133. Reibe, C.; Knez, Z.; Weidner, E. A new high-pressure micronisation process for the gentle processing of high molecular mass gelatine. Food Bioprod. Proc. 2012, 90, 79-86. [CrossRef]

134. Nuchuchua, O.; Every, H.A.; Hofland, G.W.; Jiskoot, W. Scalable organic solvent free supercritical fluid spray drying process for producing dry protein formulations. Eur. J. Pharm. Biopharm. 2014, 88, 919-930. [CrossRef] [PubMed]

135. Bouchard, A.; Jovanovic, N.; Jiskoot, W.; Mendes, E.; Witkamp, G.-J.; Crommelin, D.J.A.; Hofland, G.W. Lysozyme particle formation during supercritical fluid drying: Particle morphology and molecular integrity. J. Supercrit. Fluids 2007, 40, 293-307. [CrossRef]

136. De Marco, I.; Reverchon, E. Supercritical carbon dioxide plus ethanol mixtures for the antisolvent micronization of hydrosoluble materials. Chem. Eng. J. 2012, 187, 401-409. [CrossRef]

137. Adami, R.; Osseo, L.S.; Reverchon, E. Micronization of lysozyme by supercritical assisted atomization. Biotechnol. Bioeng. 2009, 104, 1162-1170. [CrossRef]

138. Wang, Q.; Guan, Y.-X.; Yao, S.-J.; Zhu, Z.-Q. Controllable preparation and formation mechanism of BSA microparticles using supercritical assisted atomization with an enhanced mixer. J. Supercrit. Fluids 2011, 56, 97-104. [CrossRef]

139. Du, Z.; Guan, Y.-X.; Yao, S.-J.; Zhu, Z.-Q. Supercritical fluid assisted atomization introduced by an enhanced mixer for micronization of lysozyme: Particle morphology, size and protein stability. Int. J. Pharm. 2011, 421, 258-268. [CrossRef] [PubMed]

140. Shen, Y.-B.; Cuan, Y.-X.; Yao, S.-J. Supercritical fluid assisted production of micrometric powders of the labile trypsin and chitosan/trypsin composite microparticles. Int. J. Pharm. 2015, 489, 226-236. [CrossRef]

141. Trivedi, V.; Bhomia, R.; Mitchell, J.C. Myristic acid coated protein immobilised mesoporous silica particles as $\mathrm{pH}$ induced oral delivery system for the delivery of biomolecules. Pharm. 2019, 12, 153. [CrossRef]

142. Gañan, N.; Bordón, M.G.; Ribotta, P.D.; González, A. Study of chia oil microencapsulation in soy protein microparticles using supercritical $\mathrm{CO}_{2}$-assisted impregnation. J. $\mathrm{CO}_{2}$ Util. 2020, 40, 101221. [CrossRef]

143. Lima, J.C.; Seixas, F.A.V.; Coimbra, J.S.R.; Pimentel, T.C.; Barão, C.E.; Cardozo-Filho, L. Continuous fractionation of whey protein isolates by using supercritical carbon dioxide. J. $\mathrm{CO}_{2}$ Util. 2019, 30, 112-122. [CrossRef]

144. Lima, J.C.; Bonfim-Rocha, L.; Barao, C.E.; Coimbra, J.S.R.; Cardozo-Filho, L. Techno-Economic assessment of $\alpha$-Lactalbumin and $\beta$-Lactoglobulin fractionation from whey protein isolated solution using supercritical carbon dioxide in a continuous reactor. $J$. Taiwan Inst. Chem. Eng. 2021, 118, 87-96. [CrossRef]

145. Martin, A.; Weidner, E. PGSS-drying: Mechanisms and modeling. J. Supercrit. Fluids 2010, 55, 271-281. [CrossRef]

146. Seifried, B.; Temelli, F. Supercritical fluid drying of high molecular weight biopolymers for particle formation and delivery of bioactives. In Proceedings of the 10th International Symposium Supercritical Fluids (ISSF2012), San Francisco, CA, USA, 13-16 May 2012.

147. Rodrigues, M.A.; Li, J.; Padrela, L.; Almeida, A.; Matos, H.A.; de Azevedo, E.G. Anti-solvent effect in the production of lysozyme nanoparticles by supercritical fluid-assisted atomization processes. J. Supercrit. Fluids. 2009, 48, 253-260. [CrossRef]

148. Dickinson, E. Milk protein interfacial layers and the relationship to emulsion stability and rheology. Colloids Surf. B Biointerfaces 2001, 20, 197-210. [CrossRef]

149. Liu, X.; Powers, J.R.; Swanson, B.G.; Hill, H.H.; Clark, S. Modification of whey protein concentrate hydrophobicity by high hydrostatic pressure. Innov. Food Sci. Emerg. Technol. 2005, 6, 310-317. [CrossRef]

150. Xu, D.; Yuan, F.; Jiang, J.; Wang, X.; Hou, Z.; Gao, Y. Structural and conformational modification of whey proteins induced by supercritical carbon dioxide. Innov. Food Sci. Emerg. Technol. 2011, 12, 32-37. [CrossRef]

151. Manoi, K.; Rizvi, S.S.H. Rheological characterization of texturized whey protein concentrate-based powders produced by reactive supercritical fluid extrusion. Food Res. Int. 2008, 41, 786-796. [CrossRef]

152. Liu, X.; Gao, Y.; Xu, H.; Wang, Q.; Yang, B. Impact of high-pressure carbon dioxide combined with thermal treatment on degradation of red beet (Beta vulgaris L.) pigments. J. Agric. Food Chem. 2008, 56, 6480-6487. [CrossRef]

153. Yin, C.Y.; Li, J.B.; Xu, Q.; Peng, Q.; Liu, Y.B.; Shen, X.Y. Chemical modification of cotton cellulose in supercritical carbon dioxide: Synthesis and characterization of cellulose carbamate. Carbohydr. Polym. 2007, 67, 147-154. [CrossRef]

154. Zhong, Q.; Jin, M. Enhanced functionalities of whey proteins treated with supercritical carbon dioxide. J. Dairy Sci. 2008, 91, 490-499. [CrossRef] [PubMed]

155. Monhemi, H.; Dolatabadi, S. Molecular dynamics simulation of high-pressure $\mathrm{CO}_{2}$ pasteurization reveals the interfacial denaturation of proteins at $\mathrm{CO}_{2}$ /water interface. J. $\mathrm{CO}_{2}$ Util. 2020, 35, 256-264. [CrossRef]

156. Monhemi, H.; Housaindokht, M.R. The molecular mechanism of protein denaturation in supercritical $\mathrm{CO}_{2}$ : The role of exposed lysine residues is explored. J. Supercrit. Fluids 2019, 147, 222-230. [CrossRef]

157. Vatansever, S.; Rao, J.; Hall, C. Effects of ethanol modified supercritical carbon dioxide extraction and particle size on the physical, chemical, and functional properties of yellow pea flour. Cereal Chem. 2020, 97, 1133-1147. [CrossRef]

158. Podrepsek Yoon, A.K.; Singha, P.; Rizvi, S.S.H. Steam vs. SC- $\mathrm{CO}_{2}-$ based extrusion: Comparison of physical properties of milk protein concentrate extrudates. J. Food Eng. 2021, 292, 110244. [CrossRef] 
159. Gopirajah, R.; Singha, P.; Javad, S. Emulsifying properties of milk protein concentrate functionalized by supercritical fluid extrusion. J. Food Proc. Preserv. 2020, 44, e14754. [CrossRef]

160. Ding, L.; Zhao, Q.; Zhou, X.; Tang, C.; Chen, Y.; Cai, Z. Changes in protein structure and physicochemical properties of egg white by super critical carbon dioxide treatment. J. Food Eng. 2020, 284, 110076. [CrossRef] 